\title{
Smoking-induced genetic and epigenetic alterations in infertile men
}

\author{
Sezgin Gunes, Asli Metin Mahmutoglu, Mehmet Alper Arslan and Ralf Henkel
}

\begin{abstract}
Male fertility rates have shown a progressive decrease in both developing and industrialised countries in the past 50 years. Clinical and epidemiological studies have demonstrated controversial results about the harmful effects of cigarette smoking on seminal parameters. Some studies could not establish a negative effect by tobacco smoking on sperm quality and function, whereas others have found a significant reduction in sperm quality and function. This study reviews the components in cigarette smoke and discusses the effects of smoking on male fertility by focusing extensively on smoking-induced genetic and epigenetic alterations in infertile men. Chromosomal aneuploidies, sperm DNA fragmentation and gene mutations are discussed in the first section, while changes in DNA methylation, chromatin remodelling and noncoding RNAs are discussed in the second section as part of epigenetic alterations.
\end{abstract}

\section{1 | Introduction}

Cigarette smoking is considered as a preventable cause of death (Pappas et al., 2006), and cigarette consumption throughout the world is estimated to hit 15 billion a day (Eriksen, Mackay, \& Ross, 2013). Until the end of the twenty-first century, it is predicted that tobacco use will have caused the death of about 1 billion people worldwide (Petzold et al., 2009).

Infertility affects approximately $15 \%$ of couples in the population, and the number of infertile couples tends to increase in recent decades. A malefactor solely is involved in $\sim 20 \%$ of all couples (Harris, Fronczak, Roth, \& Meacham, 2011; Male Infertility Best Practice Policy Committee of the American Urological Association \& Practice Committee of the American Society for Reproductive Medicine, 2006). Men of reproductive age (20-39 years of age) constitute approximately half of all smokers (Harlev, Agarwal, Gunes, Shetty, \& du Plessis, 2015).

Cigarette smoking and male infertility have been evaluated from various aspects including semen parameters (Asare-Anane et al., 2016; Vine, Tse, $\mathrm{Hu}$, \& Truong, 1996), sperm membrane integrity (Belcheva, Ivanova-Kicheva, Tzvetkova, \& Marinov, 2004), oxidative stress (OS) (Fraga, Motchnik, Wyrobek, Rempel, \& Ames, 1996; Saleh, Agarwal, Sharma, Nelson, \& Thomas, 2002) and genetic and epigenetic effects (De Bantel et al., 
2015; Jurewicz et al., 2015; Laqqan et al., 2017; Marczylo, Amoako, Konje, Gant, \& Marczylo, 2012). Conventional semen parameters and smoking have been found to be associated with many studies (Caserta et al., 2013; Meri, Irshid, Migdadi, Irshid, \& Mhanna, 2013; Vine, Margolin, Morrison, \& Hulka, 1994). However, results of these studies are inconsistent due to variability of the semen parameters, variations in study design, subjects and methods, revisions in laboratory examination criteria of semen analysis announced by the World Health Organization (WHO) over the years, and the complexity and heterogeneity of male infertility (Harlev, Esteves, Sharma, \& Agarwal, 2016). Smoking-induced genetic alterations have an influence on fertility through chromosomal alterations (Härkönen, Viitanen, Larsen, Bonde, \& Lähdetie, 1999; Pereira et al., 2014; Rubes et al., 1998), mutations (Yauk et al., 2007), polymorphisms (Ji, Yan, Liu, Qu, \& Gu, 2013; Yarosh, Kokhtenko, Starodubova, Churnosov, \& Polonikov, 2013; Yu et al., 2013), sister chromatid exchanges (SCE) (Papachristou et al., 2008), micronuclei (Lähdetie, 1986; Milosevic-Djordjevic, Stosic, Grujicic, Zelen, \& Sazdanovic, 2012) and DNA damage (Elshal, El-Sayed, Elsaied, El-Masry, \& Kumosani, 2009; Fraga et al., 1996; Viloria et al., 2010; Zenzes, Bielecki, \& Reed, 1999) (Figure 1). Over the last decades, the association of epigenetic factors (such as DNA methylation, chromatin remodelling and noncoding RNAs) with male infertility-related smoking has also been investigated (Dai et al., 2015; Dong et al., 2016; La Maestra, De Flora, \& Micale, 2015; Yu, Ding, et al., 2014; Yu, Qi, et al., 2014).

In this review, we provide an overview of cigarette smoke components and discuss the effects of smoking on male fertility by focusing extensively on smoking-induced genetic and epigenetic alterations in infertile men.

\section{2 | Components of cigarette smoke}

Cigarette smoke is composed of more than 7,000 chemicals, 69 of which are known as carcinogens (Esakky \& Moley, 2016). Several prominent toxic agents found in cigarette smoke include nicotine, tar, carbon monoxide, hydrogen cyanide, some volatile aldehydes, alkenes and aromatic hydrocarbons (Hoffmann, Hoffmann, \& El-Bayoumy, 2001).

\section{1 $\mid$ Nicotine}

Nicotine in tobacco smoke is one of the most toxic substances that cause addiction and can readily be detected in the serum and semen of smokers (Dai et al., 2015). Shown to act as a powerful oxidising agent, nicotine may have an impact on sperm function by altering sperm plasma membrane and DNA integrity in humans (Arabi, 2004). Human sperm cells contain nicotinic acetylcholine receptors (nAChRs) which affect sperm motility and take part in acrosome reaction (Bray, Son, \& Meizel, 2005). Nicotine and its major metabolite cotinine can be detected in seminal plasma in proportion to the dose of smoking (Zenzes, 2000). In humans, approximately $3 / 4$ of nicotine is known to be metabolised to cotinine, which in turn is metabolised to trans-3'-hydroxycotinine (Benowitz, Hukkanen, \& Jacob, 2009). Pacifici et al. have reported similar levels of cotinine and trans-3'-hydroxycotinine in both serum and seminal plasma of smokers, whereas seminal nicotine levels were found to be significantly higher than those in the serum. In the same study, total sperm motility has 
been shown to be negatively correlated with seminal cotinine and trans-3'-hydroxycotinine (Pacifici et al., 1993). Cotinine concentrations in semen and blood plasma from fertile and subfertile male smokers did not differ significantly; however, a small but significant correlation was found between cotinine concentrations in seminal plasma and the ratio of spermatozoa with abnormal morphology $\left(r_{\mathrm{S}}=0.19, p<0.01\right)$ (Wong et al., 2000). Nicotine and cotinine may lead to vasoconstriction reducing tissue oxygenation and can accumulate in the tissues of reproductive organs (Sadeu, Hughes, Agarwal, \& Foster, 2010).

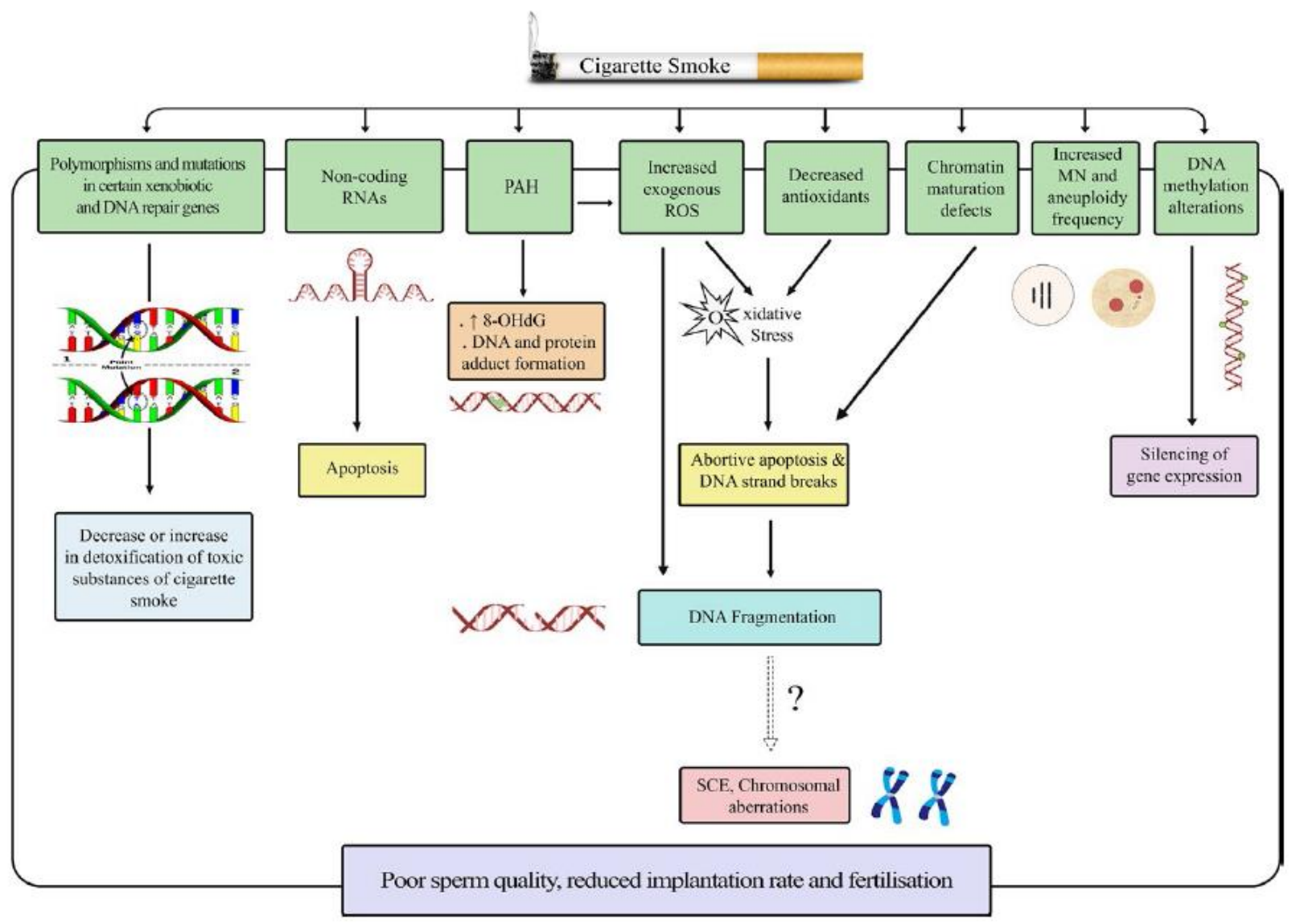

FIGURE 1 Smoking-induced genetic and epigenetic alterations associated with male infertility

Nicotine causes alterations in the levels of reproductive hormones as well. Follicle-stimulating hormone (FSH)/testosterone and luteinising hormone ( $\mathrm{LH}$ ) are key endocrine hormones responsible for the regulation of testicular functions and spermatogenesis (Ramaswamy \& Weinbauer, 2014). A study conducted with albino rats has shown that nicotine decreases levels of testosterone in both low- and high-dose groups, whereas FSH levels decrease and LH levels increase only in the high-dose (1.0 $\mathrm{mg} / \mathrm{kg}$ ) group ( $p<0.05$ ) (Oyeyipo, Raji, \& Bolarinwa, 2013). Decrease in testosterone levels may cause a deterioration of malefactor fertility (Aitken, 2014). Many studies have reported various genotoxic effects caused by nicotine not only in human spermatozoa (Ginzkey et al., 2013). 
Apart from its association with sperm morphology and quantity, nicotine might also have a negative impact on the attachment and penetration of human spermatozoa to the ovum. In a study performed with zona-free hamster eggs, nicotine has been shown to lead to a significant dose-dependent decrease in the percentages of eggs attached with spermatozoa, as well as in the rate of sperm penetration (Pekarsky, Rust, Varn, Mathur, \& Mathur, 1995). These findings have demonstrated that nicotine adversely affects both sperm membrane function and ability to fertilise the ovum.

Several animal and cell culture studies have investigated the effect of nicotine exposure in the prenatal period and found out that nicotine leads to poor pregnancy outcomes and health conditions in both male and female offspring. The adverse effects of nicotine on reproductive organs and placenta have been suggested to be, at least in part, mediated via increased levels of oxidative and ER stresses and inflammation (Wong, Barra, Alfaidy, Hardy, \& Holloway, 2015).

\section{2 | Polycyclicaromatichydrocarbons}

Polycyclic aromatic hydrocarbons (PAHs) are products generated as a result of incomplete combustion of organic materials (Lodovici, Akpan, Evangelisti, \& Dolara, 2004). Metabolites like PAHs found in cigarette smoke can induce an inflammatory response in the male reproductive tract, which in turn results in leucocyte infiltration and recruitment into the semen, increasing levels of reactive oxygen species (ROS) (Saleh et al., 2002).

Benzo[a]pyrene $(\mathrm{BaP})$ is one of the most studied polycyclic aromatic hydrocarbons found in cigarette smoke and is highly mutagenic and carcinogenic (Hu \& Hou, 2015; Zenzes, 2000). $\mathrm{BaP}$ has been reported to induce disease phenotypes (Marczylo et al., 2012) and mutations that can be transmitted to future offspring. BaP exposure may result in hypomethylation at LINE-1, SINE-B1 and SINE-B2 loci in the testes (Godschalk et al., 2015). BaP can also cause an increase in sperm hyper-activation that is essential for sperm cells for acquisition of fertilising capability, resulting in premature and erroneous acrosome reaction. Using normospermic semen samples from nonsmoking men, Gutgutia et al. (2008) have shown that increased concentrations of $\mathrm{BaP}(\geq 50 \mu \mathrm{g} / \mathrm{ml})$ lead to an increase in sperm hyperactivation, promoting a premature and erroneous acrosome reaction.

\subsection{Heavy metals}

\subsection{1 | Cadmium}

Cadmium (Cd) is a toxic heavy metal found in water, air, soil, crop plants and tobacco leaves (Lugon-Moulin, Martin, Krauss, Ramey, \& Rossi, 2006). Cd, one of the principal components of cigarette smoke, can be found about 1.0-2.0 $\mu \mathrm{g}$ per cigarette and progressively accumulates in the blood and in different organs of the body over time. Necroscopic analyses have revealed a linear age-dependent accumulation of $\mathrm{Cd}$ due to smoking in seminal vesicles, epididymides, ovarian and testicular tissues from deceased individuals (Zenzes, 2000). 
Human testicles and spermatozoa contain calcium $\left(\mathrm{Ca}^{2+}\right)$ and potassium $\left(\mathrm{K}^{+}\right)$channels that play a role in the early phases of acrosome reactions. These channels provide metallic toxic agent access to mature spermatozoa, and polymorphisms in their respective genes result in differential sensitivities to $\mathrm{Cd}^{2+}$ and lead $\left(\mathrm{Pb}^{2+}\right)$. For example, high levels of $\mathrm{Cd}^{2+}$ have been reported in varicocele-associated infertility, whereas high $\mathrm{Pb}^{2+}$ levels have been associated with unexplained infertility (Benoff, Jacob, \& Hurley, 2000).

In smokers, decreased enzymatic activity of sperm plasma membrane $\mathrm{Ca}^{2+}$ ATPase leading to reduced sperm motility has been attributed to increased cadmium levels in the seminal fluid. Cadmium concentration has been found to be twice as much in smokers than in nonsmokers both in the fertile and infertile groups (Kumosani, Elshal, Al-Jonaid, \& Abduljabar, 2008). As a potent inhibitor of 8-oxoguanine DNA glycosylase (OGG1), a significant DNA base excision repair enzyme, Cd exposure also causes an increase in oxidised base adducts in the sperm DNA (Aitken, 2014).

\subsection{2 | Lead}

Lead is another heavy metal found in cigarette and cigarette smoke (Hoffmann et al., 2001). Among infertile men, seminal plasma of smokers has been found to contain significantly higher levels of lead than those of nonsmokers (Kiziler et al., 2007). In men with high levels of lead originating from environmental exposure, it has been reported that sperm count was significantly lower, although sperm volume, motility and morphology seemed not to be negatively affected (Wu et al., 2012).

\section{4 | Arsenic}

Cigarette smoke is known to contain trace amounts of arsenic (Besingi \& Johansson, 2014). Arsenic has a carcinogenic effect in humans and is found within a range of 40-120 $\mu \mathrm{g}$ per unfiltered cigarette (Hoffmann et al., 2001). Environmental contaminants including arsenic have been reported to cause sperm DNA damage (Jahan et al., 2016) and epigenetic changes in Leydig cells. In a study conducted with mouse Leydig cell line culture, both low and high concentrations of arsenic resulted in changes in DNA methylation status (Singh \& DuMond, 2007). Low level of environmental arsenic exposure has also been found to be related to unexplained male infertility (Wang et al., 2016).

\section{3 | Effects of smoking on male fertility}

Smoking, including both active and passive smoking, is known to have negative effects on multiple organs and systems which culminate in cardiovascular and pulmonary diseases, skeletal disorders, various types of cancers, early developmental problems as well as problems in fertility and reproduction (Cusano, 2015; Marczylo et al., 2012; Phillips \& Venitt, 2012). Among the environmental factors that affect human fertility, smoking remains to be the best studied one (Mendiola et al., 2008). Although current data failed to establish a causal relationship between smoking and decline in male fertility, fertilising capacity of spermatozoa obtained from smokers is known to be less than that of 
nonsmokers and embryos generated using assisted reproductive techniques have reduced implantation rates (Mostafa, 2010).

Many studies in the literature have investigated the relationship between smoking and male infertility. Some of those studies have found associations between smoking and poor semen quality (Asare-Anane et al., 2016; Caserta et al., 2013; Sharma, Harlev, Agarwal, \& Esteves, 2016; Vine et al., 1994), chromosomal and morphological abnormalities of sperm cells (Alvarez, 2015; Mak et al., 2000; Ozgur, Isikoglu, Seleker, \& Donmez, 2005), decreased seminal plasma antioxidant levels (Fraga et al., 1996), increased oxidative damage and couples' infertility (Yang et al., 2016), whereas some others have failed to find a significant relationship between smoking and classical semen parameters (Dikshit, Buch, \& Mansuri, 1987; Dunphy, Barratt, Tongelen, \& Cooke, 1991; Holzki, Gall, \& Hermann, 1991; Oldereid, Rui, \& Purvis, 1992; Osser, Beckman-Ramirez, \& Liedholm, 1992; Pasqualotto, Sobreiro, Hallak, Pasqualotto, \& Lucon, 2006). In a study conducted with infertile Turkish men, abnormalities in spermatozoa tails have been detected in heavy smokers; however, compared to light smokers, heavy smokers still had the higher ratio of rapidly progressive spermatozoa (Ozgur et al., 2005). In another study where the effect of smoking on semen quality has been investigated among infertile men, normozoospermia ratio was found to be $39 \%$ in nonsmokers, whereas it was only $3 \%$ in the smoker group. In the same study, asthenozoospermia has been suggested to be an early marker of deterioration in semen quality (Gaur, Talekar, \& Pathak, 2007). In a more recent report where the effect of smoking on sperm morphology and semen parameters as well as leucocyte infiltration has been studied, both sperm motility and percentage of abnormal sperms have been found to be significantly affected by smoking, while seminal fluid $\mathrm{pH}$ and sperm concentration seemed to stay unaffected. A large meta-analysis $(n=5,865)$ has shown a significant association with reduced sperm motility and count, suggesting more severe impairment of semen quality in moderate and heavy smokers (Sharma et al., 2016).

In conclusion, smoking exerts a detrimental effect on sperm motility, morphology and leucocyte count, which may account for one of the fundamental environmental factors underlying male subfertility (Meri et al., 2013).

\section{4 | C igarette smoking and genetic alterations 4.1 Chromosomal alterations}

Chromosomal aberrations are generally divided into two main groups: structural and numerical chromosomal abnormalities. The main mechanism causing chromosomal aneuploidies, aka numerical chromosomal abnormalities, is nondisjunction of homologous chromosomes during meiosis in human sperms (Templado, Uroz, \& Estop, 2013). Tobacco and alcohol use and various biological and environmental factors such as occupational hazard may lead to aneuploidies both in somatic and germ cells (Jurewicz et al., 2015; Shi \& Martin, 2000; Shi et al., 2001). Induction capacity of nicotine and other alkaloids was verified in various experimental systems. 
In a study investigating the connection between aneuploidies and cigarette smoking, a significantly higher frequency of chromosome 13 disomy was found in spermatozoa of smokers compared with nonsmokers with similar lifestyles and demographic characteristics; however, no variation was reported between the groups in the frequencies announced of disomy 21, $\mathrm{X}$ or $\mathrm{Y}$ in both groups. In addition, light smokers have been suggested to have a significantly lower mean frequency of XY disomy than nonsmokers. Frequencies of the sex chromosome aneuploidies were found to be higher than autosomal aneuploidies for chromosomes 13 and 21 (Shi et al., 2001). Sex chromosomes and chromosome 21 of human spermatozoa have been proposed to be more prone to nondisjunction than other autosomal chromosomes (Templado et al., 1996). A recent study has evaluated the effect of smoking on the levels of disomy for chromosomes $3, \mathrm{X}$ and $\mathrm{Y}$ in spermatozoa derived from male smokers with normal somatic karyotype. The study demonstrated that the frequency of $\mathrm{XX}$ and $\mathrm{YY}$ disomies did not reveal any differences between smokers and nonsmokers; however, the total disomy of chromosomes $3, \mathrm{X}$ and $\mathrm{Y}$ was found to be higher in smokers than in nonsmokers $(p<0.0001)$. Moreover, the study showed a statistically significant increase in disomy of chromosomes X, Y and particularly 3 in the smoking group in comparison with the nonsmoking control group. The frequency of diploid sperm $\mathrm{XY}_{33}$ was detected to be higher than the frequencies of diploid $\mathrm{XX}_{33}$ and YY33 sperm cells, indicating the importance of some exogenous agents in meiosis I ( $p<$ o.0167) (Pereira et al., 2014). Although underlying mechanisms remain yet undefined, some men are known to be more susceptible to smoking-induced meiotic nondisjunction than others, which suggests there might be a genetic variation and/or epigenetic component (Shi et al., 2001). In addition to nondisjunction, decreased or absent meiotic recombination may elevate aneuploidy frequency in sperm cells and result in infertility (Templado et al., 2013).

\subsection{Sperm DNAfragmentation and damage}

Sperm DNA fragmentation (SDF) is the most frequently encountered DNA anomaly in human spermatozoa (García-Ferreyra, 2015) and has been widely accepted as an important marker during fertility assessment (Agarwal et al., 2016). SDF was found to be correlated with conventional semen parameters (Evgeni, Lymberopoulos, Touloupidis, \& Asimakopoulos, 2015; Moazzam, Sharma, \& Agarwal, 2015; Samplaski et al., 2015), fertilisation rate (Benchaib et al., 2003) and failure (Lopes, Sun, Jurisicova, Meriano, \& Casper, 1998), recurrent pregnancy loss (Brahem et al., 2011; Zidi-Jrah et al., 2016) and the speed of morphokinetic parameters (Wdowiak, Bakalczuk, \& Bakalczuk, 2015) and postimplantation development of the embryo (Borini et al., 2006).

Apoptosis has been suggested to be the main reason of sperm DNA fragmentation, which is induced by oxidative stress and chromatin maturation defects in male gonads (Muratori et al., 2015). Cigarette smoke extract can trigger apoptosis and chromatin condensation of spermatozoa (Calogero et al., 2009). Compared to non-smokers, smoking has been reported to increase DNA fragmentation ratio by $\sim 1.2$-fold in spermatozoa of smokers $(p<0.001)$ (Sepaniak et al., 2006). Studies investigating the effect of cigarette smoking on DNA fragmentation are summarised in Table 1. Notwithstanding most of the studies found a significant association between smoking and SDF and/or various seminal parameters (Cui, 
Jing, Wu, Wang, \& Li, 2016; El-Melegy \& Ali, 2011; Sun, Jurisicova, \& Casper, 1997; Taha, Ezz-Aldin, Sayed, Ghandour, \& Mostafa, 2014), some of the studies failed to find any association between them (Belcheva et al., 2004; De Bantel et al., 2015). Elshal et al. have studied effects of cigarette smoking on sperm DNA fragmentation, semen parameters and abnormally high DNA stainability (HDS) in a group comprising of infertile smokers ( $n=$ $34)$, infertile nonsmokers $(n=36)$ and fertile nonsmokers $(n=16)$. The authors reported a significant positive correlation between smoking and the percentage of DNA fragmentation index (DFI), HDS\% and abnormal morphology $(r=0.796, p=0.0001 ; r=0.371, p=0.033 ; r$ $=0.591, p<0.001$ respectively). DFI was higher in infertile smokers than in infertile or fertile nonsmokers $(37.66 \pm 4.03,19.34 \pm 7.13,14.51 \pm 4.91$, respectively, $p<0.001)$ (Elshal et al., 2009). Sperm morphological abnormalities have also been found to be associated with an increase in DNA fragmentation. Although DFI was not statistically different between asthenozoospermic and normozoospermic men, it was higher in teratozoospermic men compared with their fertile controls $(21.37 \pm 17.26 \%$ and $8.19 \pm 6.84 \%$, respectively, $p<$ o.001) (Mehdi, Khantouche, Ajina, \& Saad, 2009), confirming the previous studies finding an association between DNA fragmentation and morphological abnormality of the sperm. In oligoasthenoteratozoospermic men with varicocele, significant negative correlations were detected between the duration and the frequency of smoking habit and sperm motility, whereas significant positive correlations were found between DNA fragmentation and seminal ROS levels (Taha et al., 2014) (Table 2).

OS caused by oxygen and ROS (Agarwal, Virk, Ong, \& du Plessis, 2014) gives rise to DNA damage and deteriorations in sperm epigenome, resulting in infertility (Bisht, Faiq, Tolahunase, \& Dada, 2017). Cigarette smoke containing 1,015 free radicals per puff induces OS in the male reproductive tract (Sundar, Yao, \& Rahman, 2013). OS-induced DNA damage has an adverse effect on sperm quality in humans as well (Micillo et al., 2016). Cigarette smoke has been proposed to decrease the levels of the antioxidants alpha-tocopherol and ascorbic acid in seminal plasma proportionally with the dose and duration of smoking and to increase oxidative damage in human spermatozoa (Fraga et al., 1996). Ascorbic acid level of seminal plasma was also found to be lower in smokers and infertile men versus nonsmokers and fertile men (Mostafa et al., 2006). Smoking had an adverse effect on mRNA expression of the antioxidants enzymes glutathione peroxidase 1 (GPx-1) and glutathione peroxidase 4 (GPx-4), but did not lead to sperm oxidative DNA damage. 
TABLE 1 Smoking-induced chromosomal aneuploidies in human spermatozoa

\begin{tabular}{|c|c|c|}
\hline Chromosomes & Conclusion(s) & Reference \\
\hline $\mathrm{X}, \mathrm{Y}, 18$ & XX18 aneuploidy in smokers $\uparrow$ & $\begin{array}{l}\text { Robbbins, Vine, Truong } \\
\& \text { Everson, } 1997\end{array}$ \\
\hline$X, Y, 8$ & Frequency of $Y Y$ disomy in smokers $\uparrow$ & $\begin{array}{l}\text { Rubes, Lowe, Moore, } \\
\text { Perreault, Slott, } \\
\text { Evenson, Selevan, \& } \\
\text { Wyrobek, } 1998\end{array}$ \\
\hline 1 and 7 & $\begin{array}{l}\text { Frequency of disomy } 1 \text { in smokers } \uparrow \\
\text { Frequency of disomy } 7 \text { in smokers } \uparrow \downarrow\end{array}$ & $\begin{array}{l}\text { Harkonene, Viitanen, } \\
\text { Larsen, Bonde, \& } \\
\text { Lahdetie, } 1999\end{array}$ \\
\hline$X, Y, 13,21$ & $\begin{array}{l}\text { Frequency of disomy } 13 \text { in smokers } \uparrow \\
\text { Frequency of } X Y \text { disomy in light smokers } \downarrow \\
\text { Frequencies of } 21, X \text { and } Y \text { disomy in smokers } \\
\text { and nonsmokers } \uparrow \downarrow\end{array}$ & $\begin{array}{l}\text { Shi, Ko, Barclay, Hoang, } \\
\text { Rademaker, \& Martin, } \\
2001\end{array}$ \\
\hline X, Y, 3 & $\begin{array}{l}\text { Frequencies of total } \mathrm{X}, \mathrm{Y} \text { and } 3 \text { disomy in } \\
\text { smokers } \uparrow \\
\text { Sperm cells with XY33 ve YY33 in smokers } \uparrow\end{array}$ & $\begin{array}{l}\text { Perreira, Juchniuk de } \\
\text { Vozzi, Dos Santos, } \\
\text { Vasconcelos, De Paz, } \\
\text { Squire, \& Martelli, } 2014\end{array}$ \\
\hline
\end{tabular}

Note. $\uparrow:$ increase; $\downarrow$ : decrease; $\uparrow \downarrow$ : no change. 


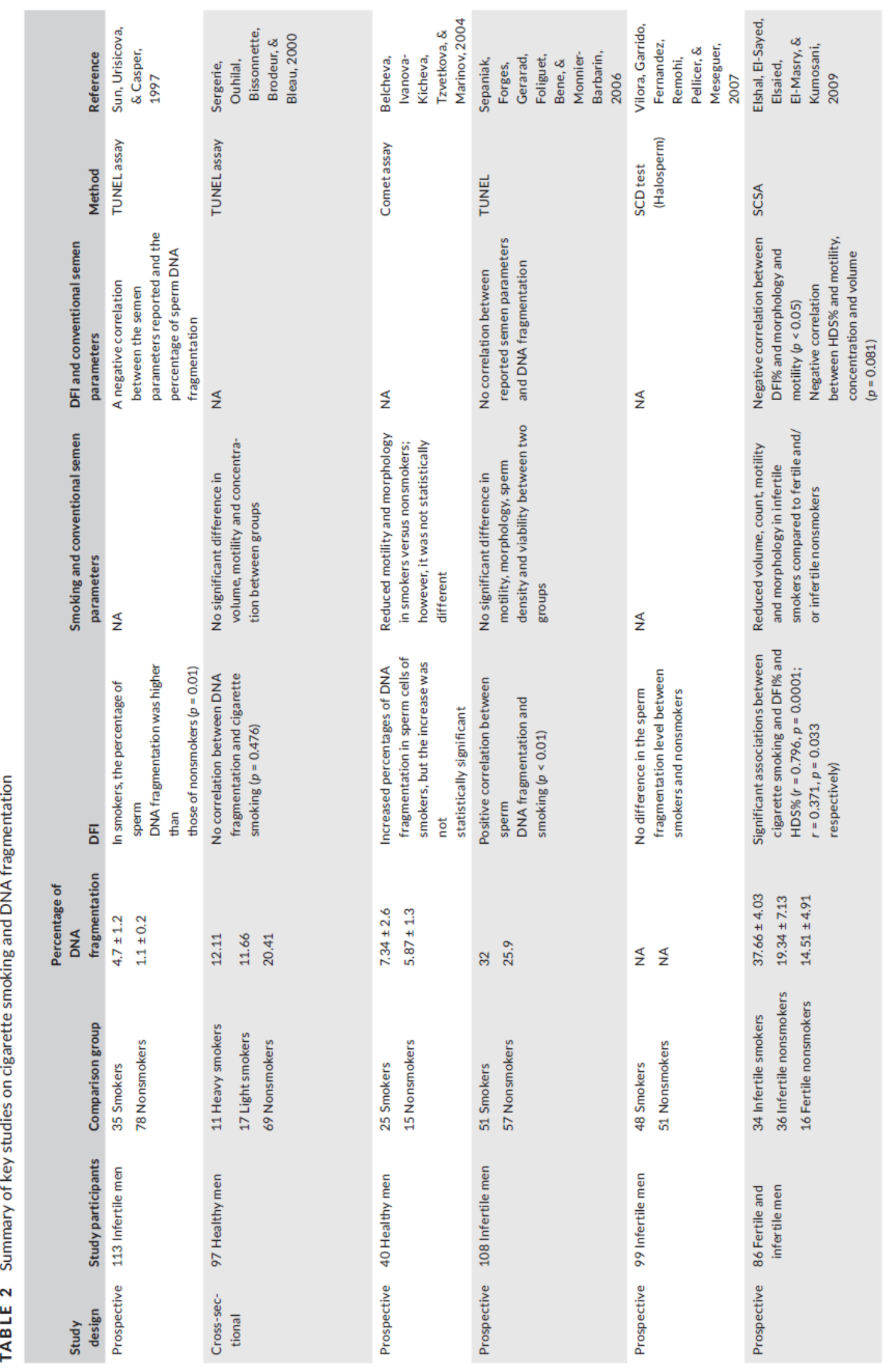




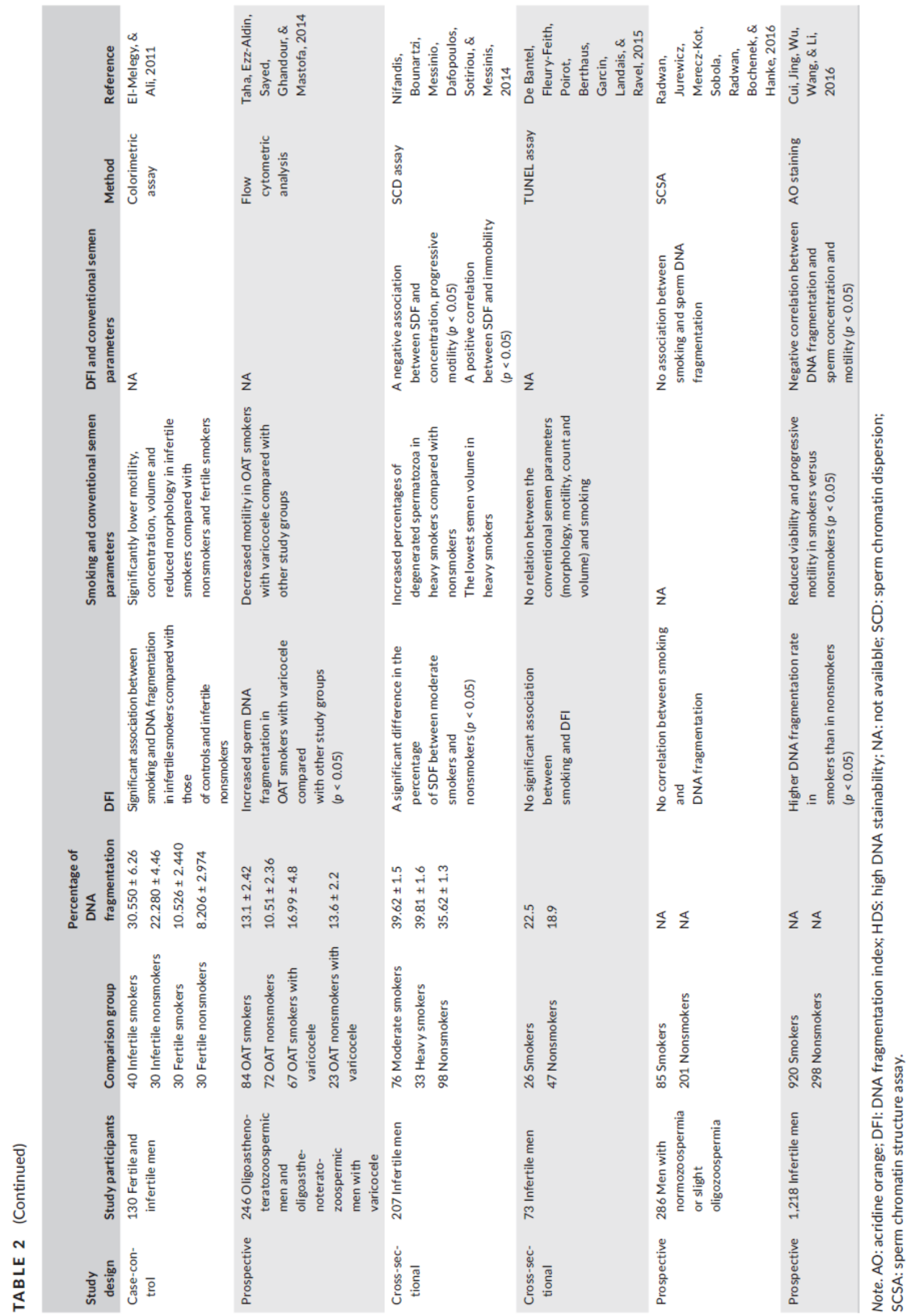


GPx-1 and GPx-4 isoforms are related with sperm motility and male infertility respectively. Therefore, the findings of this study suggest that the effect of smoking on sperm motility may be mediated by GPx-1(Viloria et al., 2010). 8-hydroxy-2'-deoxyguanosine (8-OHdG) that is an indicator of sperm DNA damage (Fraga et al., 1996) has been proposed to be higher in spermatozoa of healthy smokers than in nonsmokers (Shen \& Ong, 2000). Spermatozoa from infertile men have elevated levels of 8-OHdG compared with leucocytes of infertile men (Guz et al., 2013). Increased leucocyte concentration in seminal plasma of infertile smokers has been proposed to explain in part the increased levels of seminal OS in these men (Saleh et al., 2002). OS markers have diminished in the plasma of active smokers when smoking was given up, suggesting a clear correlation between smoking and OS (Petruzzelli et al., 2000).

Exposure to cigarette smoke can result in the formation of DNA and protein adducts due to both reactive nitrogen species (RNS) and ROS-like compounds (Harlev et al., 2015). PAH causes an increase in ROS level and forms adduct via binding to DNA covalently. Such adducts arising from smoking have been identified in male and female germ cells, preimplantation embryos and granulosa cells (Zenzes, 2000). Benzo(a)pyrene diol epoxide 1 (BPDE1) is a carcinogenic reactive metabolite of $\mathrm{BaP}$ and forms a DNA adduct by covalently (binding to the 2-amino group of guanosine, Zenzes, 2000). BPDE-DNA adduct levels were found to be higher in sperm cells of heavy smokers ( $\geq 20$ cigarettes/day) than in those of nonsmokers (Zenzes, Bielecki, et al., 1999). Sperm concentration and sperm motility are among other parameters that have been found to be significantly negatively associated with the level of DNA adducts in infertile men $(p<$ o.029) (Horak, Polanska, \& Widlak, 2003). Formation of DNA adducts in sperm cells may give rise to carcinogenic damage and prezygotic DNA damage that can be transmitted to offspring (Perrin et al., 2011), as evidenced by the detection of paternally derived BPDE-DNA adducts in preimplantation embryos (Zenzes, Puy, Bielecki, \& Reed, 1999).

\subsubsection{Animal studies associated with sperm DNA fragmentation and damage}

In mice, testis and epididymal sperms are known to be highly susceptible to OS-induced DNA damage (Rajesh Kumar, Doreswamy, Shrilatha, \& Muralidhara, 2002). Cigarette smoke exposure has been negatively correlated with epididymal sperm count and weight of the epididymis and seminal vesicles in rats (Abdul-Ghani, Qazzaz, Dabdoub, Muhammad, \& Abdul-Ghani, 2014).

In a study conducted with a mouse spermatocyte cell line, cigarette smoke condensate was shown to alter the expression of some other antioxidant enzymes (Sod1, Sod2 and Cyp1a1) in a dose-dependent manner (Esakky, Hansen, Drury, \& Moley, 2012).

\section{3 $\mid$ Sister chromatid exchange}

Sister chromatid exchange is the exchange of genetic material between two identical sister chromatids (Wilson \& Thompson, 2007). To date, only one study has reported an association between SCE and male infertility. The study has demonstrated that infertile men with various semen parameters exhibited a significantly high level of mean SCE 
(Papachristou et al., 2008); however, nonsmokers were not included. An elevated level of SCE frequency and infertility is also involved in the pathophysiology of Bloom syndrome which is an autosomal recessive disorder (El Ghamrasni et al., 2015). Studies mentioned above have demonstrated that SCE is associated with smoking and malefactor infertility; therefore, smoking-induced SCE may be one of the reasons of infertility in men.

\section{4 | Micronucleus}

Micronuclei, Howell-Jolly bodies, are small and nucleus-like structures that differ from the main nucleus and are derived from whole or acentric chromatids/chromosomes during mitosis (Milosevic-Djordjevic et al., 2012). Micronucleus is one of the nuclear abnormalities known to be a marker of cell damage induced by genotoxic and/or mutagenic agents (Cavalcante, Sposito, Crispim, Nascimento, \& Grisolia, 2017). A variety of factors including cigarette smoke can change the impact of genotoxic agents on the micronucleus frequency (Luzhna, Kathiria, \& Kovalchuk, 2013). Exposure to cigarette smoke and hookah lead to increased micronucleus frequency (Cavalcante et al., 2017; Derici Eker et al., 2016). Several mechanisms have been proposed to explain micronuclei formation. One proposal is that the acentric chromatid/chromosomes originated as a result of misor unrepaired DNA strand breaks. The alternative hypotheses are whole chromatid/chromosomes originate from kinetochore and spindle fibre defects, mutations in genes encoding proteins involved in anaphase checkpoint and DNA repair mechanism and alterations in the methylation status of centromeric or paracentromeric sequences (Annangi, Bonassi, Marcos, \& Hernandez, 2016; Luzhna et al., 2013). Micronucleus frequency of spermatids in the semen sample has been suggested as a marker for infertility risk (Fenech, 2011). A pioneering study in the literature reporting the presence of micronuclei in spermatids analysed semen samples of 62 smokers and nonsmokers with subfertility and six smokers with proven fertility. Among subfertile men, the frequency of spermatids with micronucleus in smokers $(n=34)$ was found to differ from nonsmokers $(n=20)$, but the difference was not statistically significant (1.15 $\pm 1.42,0.82 \pm 1.30$ respectively). Compared to fertile couples, Trkova, Kapras, Bobkova, Stankova, and Mejsnarova (2000) have observed higher micronucleus frequencies in couples with idiopathic infertility or more than one abortion. Therefore, Milosevic-Djordjevic et al. (2012) have also shown that micronucleus frequency was higher in men with reproductive failure than in healthy controls $(p<0.001)$; however, they failed to find a significant association among smoking, conventional semen parameters and micronucleus frequency.

\section{5 $\mid$ Polymorphisms and mutations}

Polymorphisms and mutations in certain genes involved in male gametogenesis might have been suggested to be responsible for spermatogenic defects, especially in idiopathic cases (Nuti \& Krausz, 2008). rs696 polymorphism of $\mathrm{I}_{\mathrm{K}} \mathrm{Ba}$ gene was found to be associated with defective spermatogenesis in nonsmokers, and smoking was demonstrated to reduce this association. Based on this finding and some in vitro gene expression experiments performed with cigarette smoke condensate, it has been proposed that smoking-related ROS might cause decreased I $\mathrm{I} B \alpha$ transcription and might be associated with defective spermatogenesis via increased NF-kB activation (Yu, Ding, et al., 2014; Yu, Qi, et al., 2014). 
Polymorphisms and/or genetic variations in xenobiotic metabolism (e.g., NAT2, GSTM1, GSTT1, GSTP1 and CYP1A1) and DNA repair (OGG1) genes may elevate susceptibility to infertility in smokers (Harlev et al., 2015) Genetic variants of xenobiotic metabolism genes involved in the detoxification of endo- and/or exogenous compounds were found to be associated with smoking in infertile men. Glutathione S-transferases (GSTs), isoenzymes of GSTM1, GSTT1 and GSTP1, are the primary defensive antioxidant systems against OS and reduce ROS to less reactive metabolites to protect the organism. Recent studies have been shown a significant relationship between smoking and GSTM1+/GSTT1 del genotype and GSTP1 105IV/GSTT1 polymorphisms in infertile men. Infertile men with $105 \mathrm{VV}$ genotype of GSTP1 gene were reported to be more sensitive to environmental toxicants (e.g., cigarette smoke) (Yarosh, Kokhtenko, Churnosov, Solodilova, \& Polonikov, 2014). CYP1A1 is one of the xenobiotic enzymes catalysing bioactivation of PAHs (Aydos, Taspinar, Sunguroglu, \& Aydos, 2009). CYP1A1 ${ }^{*} \mathrm{C}$ polymorphism (462lle/Val genotype) has been reported to increase infertility risk in smokers (OR [95\% CI] $=1.91[1.01-$ 3.59]) (Yarosh et al., 2013).

Antioxidant genes are essential for proper male gametogenesis and normal sperm function. Superoxide dismutase (SOD), nitric oxide synthase (NOS), glutathione peroxidase $(G P X)$, glutathione S- transferase (GST), nuclear factor erythroid 2-related factor 2 (NRF2) and catalase $(C A T)$ are several antioxidant genes that have been found to be associated with male infertility. The risk of male infertility might be correlated with polymorphisms or genetic variations in these genes via decreasing sperm quality (Yu \& Huang, 2015). A casecontrol study including 314 heavy smokers and 314 matched nonsmoker controls with idiopathic infertility investigated the association among polymorphisms of NRF2 gene, mRNA expression levels of GSTM1, SOD2, NRF2 and CAT antioxidant genes, and the level of seminal SOD activity. In heavy smokers, rs6721961 TT genotype of NRF2 was reported to be linked to poor semen quality (OR $[\% 95 \mathrm{CI}]=2.370$ [1.106-5.081]). Heavy smokers with the TT genotype were found to have less mRNA expressions of NRF2 and SOD2 genes than nonsmokers. The level of SOD activity also decreased significantly in heavy smokers with the TT genotype. The study has suggested that cigarette smoking and certain polymorphisms in antioxidant genes have a synergistic effect on human semen quality (Yu et al., 2013).

OGG1 is a DNA repair enzyme taking part in the removal of oxidatively damaged guanine that is generated by exogenous agents like tobacco smoke. OGG1 Ser326Cys polymorphism may increase the infertility risk in male smokers $(p=0.0003)$ by an unknown mechanism. Smokers ( $\geq 10$ cigarettes/day) with OGG1 Cys/Cys and Ser/Cys genotypes had elevated risk of infertility than smokers with wild-type Ser/Ser genotype, suggesting a gene-environment interaction between $O G G 1$ polymorphism and smoking with regard to male infertility risk (Ji et al., 2013). 
Tobacco smoke with a rich content in mutagens and carcinogens is known to cause mutations in male germ cells. Germ cell mutations can be passed on to future generations due to their hereditable nature.

\section{5 | Animal studies}

In mouse spermatogonial stem cells, $M s 6-h m$ (expanded simple tandem repeat, ESTR locus) mutations were reported to be induced by mainstream tobacco smoke. Noncoding ESTR is a sensitive marker used for the assessment of inducible germline mutations. The duration of tobacco smoke exposure gave rise to the accumulation of mutations and an increase in the mutation frequency, as evidenced by the frequency of Ms6- $\mathrm{hm}$ mutations being higher in mouse spermatogonial stem cells exposed to mainstream tobacco smoke for 12 weeks than those exposed for 6 weeks (1.7 and 1.4 times respectively) (Yauk et al., 2007). Besides mainstream tobacco smoke, sidestream tobacco smoke has also been indicated to induce Ms6-hm mutations in mouse sperm, while possibly not causing any genotoxic damage to somatic cells, highlighting adverse effects of passive smoking on the male reproductive system (Marchetti et al., 2011).

\section{6 | Cigarette smoking and epigenetic alterations}

Epigenetics is the study of mitotically and/or meiotically heritable modifications regulating genome activity without any impact on DNA sequences. Proper regulation of epigenetic processes including DNA methylation, histone modifications and nuclear protein transitions, and noncoding RNAs during gonadal development and spermatogenesis is crucial for the maintenance of embryonic development and normal sperm function (Guerrero-Bosagna \& Skinner, 2014; Gunes \& Kulac, 2013; Rajender, Avery, \& Agarwal, 2011). Fertilisation status and sperm function may be affected by changes during the epigenetic process. Sperm cells are known to have a unique epigenetic programming (Boissonnas, Jouannet, \& Jammes, 2013), and epigenomic components of the sperm cell have been proposed to be adversely affected by cigarette smoke, resulting in offspring with developmental defects (Esakky \& Moley, 2016) (Figure 1). Somatic cells of the testis involved in the regulation of spermatogenesis undergo epigenetic modifications as well (Guerrero-Bosagna \& Skinner, 2014).

\section{1 | DNA methylation}

DNA methylation in testis has unique properties, and the methylation of loci in testicular DNA differs from that in somatic tissues (Rajender et al., 2011). Methylome analysis of human sperm samples from proven fertile men has demonstrated that methylation profile of spermatozoa is unique, homogeneous and hypomethylated. Gene ontology analysis has revealed that genes with hypomethylated promoters have functions in spermatogenesis and early embryo development (Camprubi, Cigliano, Salas-Huetos, Garrido, \& Blanco, 2017). Alterations in sperm DNA methylation patterns, which may be restricted to a certain locus or repetitive sequences or may occur globally, have been associated with abnormal semen parameters and infertility (Aston et al., 2015; Du et al., 2016; Kobayashi et al., 2007; Li, Hao, Wang, Yi, \& Jiang, 2016; Marques et al., 2008; Montjean et al., 2015; Urdinguio et al., 2015; Xu et al., 2016). 
DNA methylation patterns can be modified by various environmental and lifestyle factors including cigarette smoking (Inbar-Feigenberg, Choufani, Butcher, Roifman, \& Weksberg, 2013; Lee \& Pausova, 2013). Over the recent years, the number of studies in the literature investigating the relationship between DNA methylation and smoking has been on the rise (Al Khaled, Tierling, Laqqan, Lo Porto, \& Hammadeh, 2017; Ambatipudi et al., 2016; Guida et al., 2015; Klebaner et al., 2016; Kobayashi et al., 2017; Lee, Hong, Kim, London, \& Kim, 2016; Zeilinger et al., 2013; Zhu et al., 2016). Two mechanisms regarding smoking-induced DNA have been proposed to explain methylation alterations. One proposal is that recruitment of DNA methyltransferases after DNA damage resulting from smoking. The second involves gene expression alterations due to the effect of nicotine and hypoxia caused by carbon monoxide, a principal component of cigarette smoke (Lee \& Pausova, 2013).

A recent study has investigated the association between the methylation status of SNRPN and H19 imprinting control regions and male infertility in 205 infertile men with semen pathologies and 50 normospermic men to evaluate the methylation patterns and environment interactions. Aberrant methylation of H19 and SNRPN imprinted genes has been found to be associated with male infertility and smoking has been suggested to be a risk factor by means of hypomethylation of $\mathrm{H} 19$ and hypermethylation of SNRPN in infertile men (Dong et al., 2016).

A recent genome-wide study has investigated the consistently altered DNA methylation profile within specific genomic regions including definite $\mathrm{CpG}$ islands and random DNA methylation alterations in spermatozoa from 78 smokers as compared to 78 never smokers. Data from this study have shown 141 differentially methylated CpGs associated with smoking and a genome-wide increase in sperm DNA methylation from men who smoke compared with never smokers. In addition, data suggest smoking-induced genomewide changes in paternal DNA methylation patterns might introduce increased health risk in the offspring (Jenkins et al., 2017). A similar finding was reported in a recent genome-wide study (51 smokers and 57 never smoked men) designed to assess the effect of smoking on sperm DNA methylation patterns. Significantly different methylation level (>20\%) in $11 \mathrm{CpG}$ dinucleotides has been shown in spermatozoa of current smokers compared with nonsmokers. Two of 11 CpGs (cg19169023 and cg07869343) have been found to be located in the spermatogenesis-related tyrosine-protein kinase receptor $(T K R)$ and mitogen-activated protein kinase 8 interacting protein 3 (MAPK8IP3) genes, and shown strong correlations with various semen parameters such as sperm count and motility, proposing that smoking has an adverse effect on spermatogenesis via methylation changes in the sperm DNA (Laqqan et al., 2017).

Although a significant reduction in global methylation and unchanged acetylation patterns was found after the swim-up preparation in nonsmokers, a significant elevation in 8-OHdG levels was observed only in the smoking group. In addition, increased percentage of normal form of spermatozoa and reduced DFI and 5-mC levels after swim-up were not observed in 
the smoking group suggesting a need for sperm preparation techniques appropriate for smokers (Kim, Jee, \& Kim, 2015).

\subsection{1 | Animal studies}

Smoking can change protein profiles in testis through an alteration of DNA methylation. Cigarette smoke exposure altered the expressions of 31 different proteins including phosphatidylethanolamine-binding protein 1 (PEBP1) in mouse testis. PEBP1 is an essential protein involved in spermatogenesis through its interaction with ERKs. Mice exposed to cigarette smoke were shown to have elevated methylation level near Pebp1 transcriptional start site, which has been suggested to decrease Pebp1 expression and in turn cause the inactivation of ERK pathway resulting in spermatogenetic defects (Xu et al., 2013). Apart from hypermethylation, smoking may also promote DNA hypomethylation. In mouse testis, nicotine exposure induced hypomethylation of profilin 1 (Pfni) gene encoding a protein acting in the regulation of cytoskeleton. Pfni promoter hypomethylation resulted in its overexpression, promoting actin polymerisation and presumably increasing sperm motility in mice (Dai et al., 2015).

\section{2 | Chromatin remodelling}

Male germ cells are known to have more compact chromatin structure (6- to 20-fold) than somatic cells (Boissonnas et al., 2013), therefore, the cells require unique epigenetic modifications. Unique chromatin structure of sperm cell is provided by histone-protamine exchange during spermatogenesis. Replacement of histones by protamines is a crucial step for spermiogenesis, and this step takes place via histone hyperacetylation. Early hyperacetylation of histone $\mathrm{H}_{4}$ has been proposed to cause premature nuclear protein transitioning, which ultimately results in male infertility (Rajender et al., 2011). In human spermatozoa, approximately $85 \%-90 \%$ of core histones are replaced by protamines (Hammadeh, Hamad, Montenarh, \& Fischer-Hammadeh, 2010). The remaining 10\%-15\% of histones has been indicated to be associated with telomeric sequences and essential for pronucleus formation by taking part in the signalling mechanism of the oocyte. Protamine 1 (P1) and Protamine $2\left(\mathrm{P}_{2}\right)$ are the two types of protamines in human spermatozoa playing a crucial role in chromatin condensation and male fertility. Expression changes and mutations in P1 and P2 genes have been correlated with malefactor infertility, but the underlying mechanism(s) is/are not yet known (Oliva, 2006; Yu, Ding, et al., 2014; Yu, Qi, et al., 2014).

In line with these studies, a decrease in the success of IVF outcome when using a spermatozoa with an altered $\mathrm{P} 1 / \mathrm{P} 2$ ratio has also been reported in the field of assisted reproductive technology in humans (Carrell \& Hammoud, 2010).

Cigarette smoking was found to be correlated with abnormalities in the protamination process and mRNA expression changes in both protamines in human spermatozoa ( $\mathrm{Yu}$, Ding, et al., 2014; Yu, Qi, et al., 2014). So far, only three studies have investigated the association of cigarette smoking and protamination with respect to human fertility (Hamad, Shelko, Kartarius, Montenarh, \& Hammadeh, 2014; Hammadeh et al., 2010). The first study 
demonstrated that smoking had a negative impact on $\mathrm{P} 2$ levels, and the ratio of $\mathrm{P} 1$ to $\mathrm{P} 2$ was significantly higher in smokers than in nonsmokers $\left(p<0.010,1.34 \pm 0.46 \mathrm{ng} / 10^{6}\right.$ spermatozoa and $1.11 \pm 0.2 \mathrm{ng} / 10^{6}$ sperm respectively). Structural changes in protamines and/or alterations in their DNA-binding ability or oxidative stress-induced sperm DNA damage have all been suggested as possible reasons for the negative impact of smoking on the protamination process (Hammadeh et al., 2010). In the second study, histone (H2B) ratio to the total nuclear protein $(\mathrm{H} 2 \mathrm{~B}+\mathrm{P} 1+\mathrm{P} 2)$ in spermatozoa of smokers in infertile couples was found to be higher than that of nonsmokers ( $0.29 \pm 0.07$ and $0.12 \pm 0.01$ respectively), indicating the adverse effect of smoking on the histone to protamine ratio and male fertility (Hamad et al., 2014).

Third study was designed to assess the relation between semen qualities and protamine mRNAs ratios in 64 smokers and 59 non-smokers using real-time quantitative PCR. In this study, both P1 and P2 mRNA levels in smokers were found to be significantly lower compared with those in nonsmokers. Furthermore, P1/P2 mRNA ratios were indicated to be negatively and significantly correlated with sperm count, normal sperm morphology and semen volume, suggesting that $\mathrm{P} 1 / \mathrm{P} 2$ transcripts ratios might be a useful marker for male infertility (Hamad, Shelko, Montenarh, \& Hammadeh, 2017).

\subsection{1 $\mid$ Animalstudies}

A study in mice has shown that normal levels of both P1 and P2 are essential for chromatin assembly and integrity in the sperm nucleus as well as for normal sperm function, as evidenced by haploinsufficient mice lacking either a functional Prm1 or Prm2 allele turning out infertile (Cho et al., 2001). As a continuation of this study, using the same Prm2-haploinsufficient mouse model, the authors reported increased sperm DNA damage, reduced chromatin compaction and, even more remarkably, early embryonic death following ICSI (Cho et al., 2003).

\section{3 | Noncoding RNAs}

Spermatozoa have a heterogeneous population of RNAs including coding and a variety of noncoding RNAs (Metzler-Guillemain et al., 2015). MicroRNAs (miRNAs), long noncoding RNAs (lncRNAs) and piwi-interacting RNAs (piRNAs) are among well-characterised non-coding RNAs. Environmental exposures/lifestyle factors including cigarette smoking can change the expression and function of these noncoding RNAs, having implications for defective spermatogenesis and infertility (Maccani \& Knopik, 2012).

miRNAs are 22 nucleotides long, single-stranded endogenous noncoding RNAs that inhibit gene expression by binding to their target mRNAs, leading to either mRNA cleavage/degradation or translational repression (Gunes, Arslan, Hekim, \& Asci, 2016). miRNAs are considered as potential biomarkers for smoking-related diseases and diagnosis and assessment of malefactor infertility (Abu-Halima et al., 2014; Banerjee \& Luettich, 2012; Kotaja, 2014). Infertile men with asthenozoospermia or oligoasthenozoospermia have 
demonstrated alterations in spermatozoa miRNA expression compared with men with normozoospermia. Using miRNA microarray technology, in asthenozoospermic males, a total of 77 miRNAs including miR-1973, miR-122 and miR-34b were found to be deregulated while in oligoasthenozoospermic men, expressions of 86 miRNAs including miR-19a, miR-122, miR-15b and miR-449a in addition to the aforementioned miRNAs were altered (Abu-Halima et al., 2013). Smoking can have an effect on the expression of miRNAs in human spermatozoa. Using microarray analysis, mRNA and miRNA profiles in spermatozoa have been assessed to find out the potential variation in eight smokers and eight nonsmokers. In this study, 23 miRNAs and 15 mRNAs in spermatozoa were found to be differentially expressed in smokers versus nonsmokers. In addition, the expression of 16 miRNAs was found to be significantly upregulated, whereas seven miRNAs were downregulated in smokers. A negative correlation was reported between the levels of miRNAs and their potential target mRNAs, concluding smoking-induced miRNA expression changes may promote alterations in mRNA expression in smokers (Metzler-Guillemain et al., 2015).

Compared to nonsmokers, spermatozoa from smokers have been indicated to show differential expression pattern in 28 miRNAs (such as miR-652, miR-509-5p, miR-519d, miR-146b-5p and miR-30c), which seem to regulate key signalling pathways critical for sperm quality and normal embryo development, particularly through apoptosis (Marczylo et al., 2012).

Further extensive studies are required to elucidate the effects of smoking-related miRNA changes on the spermatogenic process in infertile men. The relationship between smoking and lncRNAs in the context of male reproductive system has been much less studied in the literature.

\section{7 | Conclusion}

Tobacco use is still common and more young people become addicted in the world despite well-known adverse long-term consequences on health. Although the adverse effects of smoking are known to be a risk factor for sperm quality and fertilisation ability, the underlying mechanisms still remain poorly understood. Therefore, understanding the mechanisms of smoking-induced effects continues to be an important area of research. Of late, many studies have indicated that cigarette smoking causes a decrease in semen quality including density, motility, morphology and viability of spermatozoa and semen volume in smokers. In addition, smoking leads to reproductive hormone system alterations and abnormalities in spermatogenesis. Although the deleterious effects of cigarette smoking on male fertility are well documented, most of the male smokers are still fertile (Mostafa, 2010), and yet some studies have shown a lack of association between smoking and fecundity. In addition, cigarette smoking may lead to poor pregnancy outcomes and developmental defects in both male and female offspring.

The main hypothesis as to the role of cigarette smoke on male infertility ultimately proposes that it induces high levels of OS in the male germline. Elevated levels of OS leads 
to impairment in fertilisation, changes in genetic components including spermatozoa DNA damage, SCE, gene mutations and micronucleus formation and alterations in epigenetic profile of germ cells. In addition, chemicals in the cigarette smoke can induce sperm aneuploidies that might lead to habitual abortion and foetal developmental disorders. Recent studies have suggested smoking can induce epigenetic alterations associated with male infertility. Furthermore, dose-dependent correlations are important between smoking and semen parameters, sperm impairment, fertility potential and embryo development. However, comprehensive elucidation of the adverse effects of smoking on fertility will require well-designed extensive studies using advanced cellular and molecular techniques.

\section{Conflict of interest}

We would like to declare that there is no conflict of interest that could be perceived as prejudicing the impartiality of the research reported.

\section{ORCID}

Sezgin Gunes ～http://orcid.org/oooo-0002-3103-6482

Ralf Henkel http://orcid.org/oooo-ooo3-1128-2982 


\section{References}

Abdul-Ghani, R., Qazzaz, M., Dabdoub, N., Muhammad, R., \& Abdul-Ghani, A. S. (2014). Studies on cigarette smoke induced oxidative DNA damage and reduced spermatogenesis in rats. Journal of Environmental Biology, 35(5), 943-947.

Abu-Halima, M., Hammadeh, M., Backes, C., Fischer, U., Leidinger, P., Lubbad, A. M., ... Meese, E. (2014). Panel of five microRNAs as potential biomarkers for the diagnosis and assessment of male infertility. Fertility and Sterility, 102(4), 989-997, e981. https://doi. org/10.1016/j.fertnstert.2014.07.001

Abu-Halima, M., Hammadeh, M., Schmitt, J., Leidinger, P., Keller, A., Meese, E., \& Backes, C. (2013). Altered microRNA expression profiles of human spermatozoa in patients with different spermatogenic impairments. Fertility and Sterility, 99(5), 1249-1255, e1216. https:// doi.org/10.1016/j.fertnstert.2012.11.054.

Agarwal, A., Majzoub, A., Esteves, S. C., Ko, E., Ramasamy, R., \& Zini, A. (2016). Clinical utility of sperm DNA fragmentation testing: Practice recommendations based on clinical scenarios. Translational Andrology and Urology, 5(6), 935-950. https://doi.org/10.21037/ tau.2016.10.03

Agarwal, A., Virk, G., Ong, C., \& du Plessis, S. S. (2014). Effect of oxidative stress on male reproduction. World Journal of Men's Health, 32(1), 1-17. https://doi.org/10.5534/wjmh.2014.32.1.1

Aitken, R. J. (2014). Age, the environment and our reproductive future: Bonking baby boomers and the future of sex. Reproduction, 147(2), S1-S11. https://doi.org/10.1530/REP-13-0399

Al Khaled, Y., Tierling, S., Laqqan, M., Lo Porto, C., \& Hammadeh, M. E. (2017). Cigarette smoking induces only marginal changes in sperm DNA methylation levels of patients undergoing intracytoplasmic sperm injection treatment. Andrologia, 5O(1), e12818. https://doi. org/10.1111/and.12818

Alvarez, S. (2015). Do some addictions interfere with fertility? Fertility and Sterility, 103(1), 22-26. https://doi.org/10.1016/j. fertnstert.2014.11.008

Ambatipudi, S., Cuenin, C., Hernandez-Vargas, H., Ghantous, A., Le Calvez-Kelm, F., Kaaks, R., ... Herceg, Z. (2016). Tobacco smoking-associated genome-wide DNA methylation changes in the EPIC study. Epigenomics, 8(5), 599-618. https://doi.org/10.2217/epi-2016-0001

Annangi, B., Bonassi, S., Marcos, R., \& Hernandez, A. (2016). Biomonitoring of humans exposed to arsenic, chromium, nickel, vanadium, and complex mixtures of metals by using the micronucleus test in lymphocytes. Mutation Research, $770(\mathrm{Pt} \mathrm{A}), 140-161$. https:// doi.org/10.1016/j.mrrev.2016.03.003

Arabi, M. (2004). Nicotinic infertility: Assessing DNA and plasma membrane integrity of human spermatozoa. Andrologia, 36(5), 305-310. https://doi.org/10.1111/j.1439-0272.2004.00623.x

Asare-Anane, H., Bannison, S. B., Ofori, E. K., Ateko, R. O., Bawah, A. T., Amanquah, S. D., ... Ziem, J. B. (2016). Tobacco smoking is associated with decreased semen quality. Reproductive Health, 13(1), 90. https:// doi.org/10.1186/s12978-016-0207-z

Aston, K. I., Uren, P. J., Jenkins, T. G., Horsager, A., Cairns, B. R., Smith, A. D., \& Carrell, D. T. (2015). Aberrant sperm DNA methylation predicts male fertility status and 
embryo quality. Fertility and Sterility, 104(6), 1388-1397, e1381-e1385. https://doi.org/10.1016/j. fertnstert.2015.08.019

Aydos, S. E., Taspinar, M., Sunguroglu, A., \& Aydos, K. (2009). Association of CYP1A1 and glutathione S-transferase polymorphisms with male factor infertility. Fertility and Sterility, 92(2), 541-547. https://doi. org/10.1016/j.fertnstert.2008.07.017

Banerjee, A., \& Luettich, K. (2012). MicroRNAs as potential biomarkers of smoking-related diseases. Biomarkers in Medicine, 6(5), 671-684. https://doi.org/10.2217/bmm.12.50

Belcheva, A., Ivanova-Kicheva, M., Tzvetkova, P., \& Marinov, M. (2004). Effects of cigarette smoking on sperm plasma membrane integrity and DNA fragmentation. International Journal of Andrology, 27(5), 296-300. https://doi.org/10.1111/j.1365-2605.2004.00486.x

Benchaib, M., Braun, V., Lornage, J., Hadj, S., Salle, B., Lejeune, H., \& Guerin, J. F. (2003). Sperm DNA fragmentation decreases the pregnancy rate in an assisted reproductive technique. Human Reproduction, 18(5), 1023-1028. https://doi.org/10.1093/humrep/ deg228

Benoff, S., Jacob, A., \& Hurley, I. R. (2000). Male infertility and environmental exposure to lead and cadmium. Human Reproduction Update, 6(2), 107-121. https://doi.org/10.1093/humupd/6.2.107

Benowitz, N. L., Hukkanen, J., \& Jacob, P. 3rd (2009). Nicotine chemistry, metabolism, kinetics and biomarkers. Handbook of Experimental Pharmacology, 192, 29-60. https://doi.org/10.1007/978-3-540-69248-5_2

Besingi, W., \& Johansson, A. (2014). Smoke-related DNA methylation changes in the etiology of human disease. Human Molecular Genetics, 23(9), 2290-2297. https://doi.org/10.1093/hmg/ddt621

Bisht, S., Faiq, M., Tolahunase, M., \& Dada, R. (2017). Oxidative stress and male infertility. Nature Reviews Urology, 14(8), 470-485. https:// doi.org/10.1038/nrurol.2017.69

Boissonnas, C. C., Jouannet, P., \& Jammes, H. (2013). Epigenetic disorders and male subfertility. Fertility and Sterility, 99(3), 624-631. https://doi.org/10.1016/j.fertnstert.2013.01.124

Borini, A., Tarozzi, N., Bizzaro, D., Bonu, M. A., Fava, L., Flamigni, C., \& Coticchio, G. (2006). Sperm DNA fragmentation: Paternal effect on early post-implantation embryo development in ART. Human Reproduction, 21(11), 2876-2881. https://doi.org/10.1093/humrep/ del251

Brahem, S., Mehdi, M., Landolsi, H., Mougou, S., Elghezal, H., \& Saad, A. (2011). Semen parameters and sperm DNA fragmentation as causes of recurrent pregnancy loss. Urology, 78(4), 792-796. https://doi. org/10.1016/j.urology.2011.05.049

Bray, C., Son, J.-H., \& Meizel, S. (2005). Acetylcholine causes an increase of intracellular calcium in human sperm. Molecular Human Reproduction, 11(12), 881-889. https://doi.org/10.1093/molehr/ gah245

Calogero, A., Polosa, R., Perdichizzi, A., Guarino, F., La Vignera, S., Scarfia, A., ... Barone, N. (2009). Cigarette smoke extract immobilizes human spermatozoa and induces sperm apoptosis. Reproductive Biomedicine Online, 19(4), 564-571. https://doi.org/10.1016/j.rbmo.2009.05.004 
Camprubi, C., Cigliano, R. A., Salas-Huetos, A., Garrido, N., \& Blanco, J. (2017). What the human sperm methylome tells us. Epigenomics, 9(10), 1299-1315. https://doi.org/10.2217/epi-2017-0049

Carrell, D. T., \& Hammoud, S. S. (2010). The human sperm epigenome and its potential role in embryonic development. Molecular Human Reproduction, 16(1), 37-47. https://doi.org/10.1093/molehr/gapo9o

Caserta, D., Bordi, G., Di Segni, N., D'Ambrosio, A., Mallozzi, M., \& Moscarini, M. (2013). The influence of cigarette smoking on a population of infertile men and women. Archivesof Gynecology and Obstetrics, 287(4), 813-818. https://doi.org/10.1007/s00404-012-2643-5

Cavalcante, D. N., Sposito, J. C., Crispim, B. D., Nascimento, A. V., \& Grisolia, A. B. (2017). Genotoxic and mutagenic effects of passive smoking and urban air pollutants in buccal mucosa cells of children enrolled in public school. Toxicology Mechanisms and Methods, 27(5), 346-351. https://doi.org/10.1080/15376516.2017.1288767

Cho, C., Jung-Ha, H., Willis, W. D., Goulding, E. H., Stein, P., Xu, Z., ... Eddy, E. M. (2003). Protamine 2 deficiency leads to sperm DNA damage and embryo death in mice. $\begin{array}{lllll}\text { Biology of } & \text { Reproduction, }\end{array}$ https://doi.org/10.1095/biolreprod.102.015115

Cho, C., Willis, W. D., Goulding, E. H., Jung-Ha, H., Choi, Y. C., Hecht, N. B., \& Eddy, E. M. (2001). Haploinsufficiency of protamine-1 or -2 causes infertility in mice. Nature Genetics, 28(1), 82-86. https://doi. org/10.1038/88313

Cui, X., Jing, X., Wu, X., Wang, Z., \& Li, Q. (2016). Potential effect of smoking on semen quality through DNA damage and the downregulation of Chk1 in sperm. Molecular Medicine Reports, 14(1), 753-761. https://doi.org/10.3892/mmr.2016.5318

Cusano, N. E. (2015). Skeletal effects of smoking. Current Osteoporosis Reports, 13(5), 302-309. https://doi.org/10.1007/ s11914-015-0278-8

Dai, J., Zhan, C., Xu, W., Wang, Z., Nie, D., Zhao, X., ... Qiao, Z. (2015). Nicotine elevates sperm motility and induces Pfn1 promoter hypomethylation in mouse testis. Andrology, 3(5), 967-978. https://doi. org/10.1111/andr.12072

De Bantel, A., Fleury-Feith, J., Poirot, C., Berthaut, I., Garcin, C., Landais, P., \& Ravel, C. (2015). Simultaneous vitality and DNA-fragmentation measurement in spermatozoa of smokers and non-smokers. Cytometry Part B: Clinical Cytometry, 88(2), 120-124. https://doi. org/10.1002/cyto.b.21185

Derici Eker, E., Koyuncu, H., Sahin, N. O., Yuksel, A., Berkoz, M., Budak Diler, S., \& Altan Akgul, S. (2016). Determination of genotoxic effects of hookah smoking by micronucleus and chromosome aberration methods. Medical Science Monitor, 22, 4490-4494. https://doi. org/10.12659/MSM.898593

Dikshit, R. K., Buch, J. G., \& Mansuri, S. M. (1987). Effect of tobacco consumption on semen quality of a population of hypofertile males. Fertility and Sterility, 48(2), 334-336.

Dong, H., Wang, Y., Zou, Z., Chen, L., Shen, C., Xu, S., ... Wang, W. (2016). Abnormal methylation of imprinted genes and cigarette smoking: Assessment of their 
association with the risk of male infertility. Reproductive Sciences, 24(1), 114123. https://doi. org/10.1177/1933719116650755

Du, Y., Li, M., Chen, J., Duan, Y., Wang, X., Qiu, Y., ... Jiang, H. (2016). Promoter targeted bisulfite sequencing reveals DNA methylation profiles associated with low sperm motility in asthenozoospermia. Human Reproduction, 31(1), 24-33. https://doi.org/10.1093/humrep/ dev283

Dunphy, B., Barratt, C., Tongelen, B., \& Cooke, I. (1991). Male cigarette smoking and fecundity in couples attending an infertility clinic. Andrologia, 23(3), 223-225. https://doi. org/10.1111/j.1439-0272.1991.tbo2542.x

El Ghamrasni, S., Cardoso, R., Halaby, M. J., Zeegers, D., Harding, S., Kumareswaran, R., ... Hakem, A. (2015). Cooperation of Blm and Mus81 in development, fertility, genomic integrity and cancer suppression. Oncogene, 34(14), 1780-1789. https://doi.org/10.1038/ onc.2014.121

El-Melegy, N. T., \& Ali, M.-E.-M. (2011). Apoptotic markers in semen of infertile men: Association with cigarette smoking. International Braz J Urol, 37(4), 495-506. https://doi.org/10.1590/ S1677-55382011000400009

Elshal, M. F., El-Sayed, I. H., Elsaied, M. A., El-Masry, S. A., \& Kumosani, T. A. (2009). Sperm head defects and disturbances in spermatozoal chromatin and DNA integrities in idiopathic infertile subjects: Association with cigarette smoking. Clinical Biochemistry, 42(7-8), 589-594. https://doi.org/10.1016/j.clinbiochem.2008.11.012

Eriksen, M., Mackay, J., \& Ross, H. (2013). The tobacco atlas. Atlanta, GA: American Cancer Society.

Esakky, P., Hansen, D. A., Drury, A. M., \& Moley, K. H. (2012). Cigarette smoke condensate induces aryl hydrocarbon receptor-dependent changes in gene expression in spermatocytes. Reproductive Toxicology, 34(4), 665-676. https://doi.org/10.1016/j.reprotox.2012.10.005

Esakky, P., \& Moley, K. H. (2016). Paternal smoking and germ cell death: A mechanistic link to the effects of cigarette smoke on spermato-genesis and possible long-term sequelae in offspring. Molecular and Cellular Endocrinology, 435, 85-93. https://doi.org/10.1016/j. mce.2016.07.015

Evgeni, E., Lymberopoulos, G., Touloupidis, S., \& Asimakopoulos, B. (2015). Sperm nuclear DNA fragmentation and its association with semen quality in Greek men. Andrologia, 47(10), 1166-1174. https:// doi.org/10.1111/and.12398

Fenech, M. (2011). Micronuclei and their association with sperm abnormalities, infertility, pregnancy loss, pre-eclampsia and intra-uterine growth restriction in humans. Mutagenesis, 26(1), 63-67. https://doi. org/10.1093/mutage/geqo84

Fraga, C., Motchnik, P., Wyrobek, A., Rempel, D., \& Ames, B. (1996). Smoking and low antioxidant levels increase oxidative damage to sperm DNA. Mutation Research/Fundamental and Molecular Mechanisms of Mutagenesis, 351(2), 199203. https://doi. org/10.1016/0027-5107(95)00251-0

García-Ferreyra, J. (2015). Sperm DNA fragmentation and its relation with fertility. In B. $\mathrm{Wu}$ (Ed.), New discoveries in embryology (pp. 1-3). Rijeka, Croatia: InTech. https://doi.org/10.5772/60825. 
Gaur, D., Talekar, M., \& Pathak, V. (2007). Effect of cigarette smoking on semen quality of infertile men. Singapore Medical Journal, 48(2), 119.

Ginzkey, C., Friehs, G., Koehler, C., Hackenberg, S., Hagen, R., \& Kleinsasser, N. H. (2013). Assessment of nicotine-induced DNA damage in a genotoxicological test battery. Mutation $\quad$ Research, 351(1), 34-39. https://doi.org/10.1016/j.mrgentox.2012.11.004

Godschalk, R. W. L., Verhofstad, N., Verheijen, M., Yauk, C. L., Linschooten, J. O., van Steeg, H., ... van Schooten, F. J. (2015). Effects of benzo[a]pyrene on mouse germ cells: Heritable DNA mutation, testicular cell hypomethylation and their interaction with nucleotide excision repair. Toxicology Research, 4(3), 718-724. https://doi. org/10.1039/c4txoo114a

Guerrero-Bosagna, C., \& Skinner, M. K. (2014). Environmental epigenetics and effects on male fertility. Advances in Experimental Medicine and Biology, 791, 67-81. https://doi.org/10.1007/978-1-4614-7783-9_5

Guida, F., Sandanger, T. M., Castagne, R., Campanella, G., Polidoro, S., Palli, D., ... Chadeau-Hyam, M. (2015). Dynamics of smoking-induced genome-wide methylation changes with time since smoking cessation. Human Molecular Genetics, 24(8), 2349-2359. https://doi. org/10.1093/hmg/ddu751

Gunes, S., Arslan, M. A., Hekim, G. N. T., \& Asci, R. (2016). The role of epigenetics in idiopathic male infertility. Journal of Assisted Reproduction and Genetics, 33(5), 553-569. https://doi.org/10.1007/ s10815-016-0682-8

Gunes, S., \& Kulac, T. (2013). The role of epigenetics in spermatogenesis. Turkish Journal of Urology, 39(3), 181-187. https://doi.org/10.5152/ tud.2013.037.

Gutgutia, R., Mukhopadhyay, D., Nandi, P., Bhattacharyya, A., Banerjee, S., \& Agarwal, A. (2008). In vitro analysis of the effect of benzo-apyrene on sperm hyperactivation. Fertility and Sterility, 90, S185. https://doi.org/10.1016/j.fertnstert.2008.07.749

Guz, J., Gackowski, D., Foksinski, M., Rozalski, R., Zarakowska, E., Siomek, A., ... Olinski, R. (2013). Comparison of oxidative stress/DNA damage in semen and blood of fertile and infertile men. PLoS One, 8(7), e68490. https://doi.org/10.1371/journal.pone.0068490

Hamad, M. F., Shelko, N., Kartarius, S., Montenarh, M., \& Hammadeh, M. E. (2014). Impact of cigarette smoking on histone (H2B) to protamine ratio in human spermatozoa and its relation to sperm parameters. Andrology, 2(5), 666-677. https://doi. org/10.1111/j.2047-2927.2014.00245.x

Hamad, M., Shelko, N., Montenarh, M., \& Hammadeh, M. E. (2017). The impact of cigarette smoking on protamines 1 and 2 transcripts in human spermatozoa. Human Fertility, 1-7. https://doi.org/10.108o/ 14647273.2017.1382733

Hammadeh, M., Hamad, M., Montenarh, M., \& Fischer-Hammadeh, C. (2010). Protamine contents and $\mathrm{P} 1 / \mathrm{P} 2$ ratio in human spermatozoa from smokers and non-smokers. Human Reproduction, 25(11), 2708- 2720. https://doi.org/10.1093/humrep/deq226

Härkönen, K., Viitanen, T., Larsen, S. B., Bonde, J. P., \& Lähdetie, J. (1999). Aneuploidy in sperm and exposure to fungicides and lifestyle factors. Environmental and Molecular Mutagenesis, 34(1), 39-46. 
https://doi.org/10.1002/

(SICI)10982280(1999)34:1aabbb39:AID-EM6aaabb3.0.CO;2-F

Harlev, A., Agarwal, A., Gunes, S. O., Shetty, A., \& du Plessis, S. S. (2015). Smoking and male infertility: An evidence-based review. World Journal of Men's Health, 33(3), 143160. https://doi.org/10.5534/ wjmh.2015.33.3.143

Harlev, A., Esteves, S. C., Sharma, R., \& Agarwal, A. (2016). Reply from Authors re: Christian Leiber, Ulrich Wetterauer. The cigarette and the sperm: A fatal liaison? Eur Urol 2016;70:646-7: The cigarette and the sperm: Causality dilemma no more? European Urology, 7o(4), 647-648. https://doi.org/10.1016/j.eururo.2016.05.016

Harris, I. D., Fronczak, C., Roth, L., \& Meacham, R. B. (2011). Fertility and the aging male. Reviews in Urology, 13(4), e184-e190.

Hoffmann, D., Hoffmann, I., \& El-Bayoumy, K. (2001). The less harmful cigarette: A controversial issue. A tribute to Ernst L. Wynder. Chemical Research in Toxicology, 14(7), 767-790.

Holzki, G., Gall, H., \& Hermann, J. (1991). Cigarette smoking and sperm quality*. Andrologia, 23(2), 141-144. https://doi. org/10.1111/j.1439-0272.1991.tbo2517.x

Horak, S., Polanska, J., \& Widlak, P. (2003). Bulky DNA adducts in human sperm: Relationship with fertility, semen quality, smoking, and environmental factors. Mutation Research/Genetic Toxicology and Environmental Mutagenesis, 537(1), 5365. https://doi.org/10.1016/ S1383-5718(03)ooo51-2

Hu, Q., \& Hou, H. (2015). Tobacco smoke exposure biomarkers. Boca Raton, FL: CRC Press. Inbar-Feigenberg, M., Choufani, S., Butcher, D. T., Roifman, M.,\& Weksberg, R. (2013). Basic concepts of epigenetics. Fertility and Sterility, 99(3), 607-615. https://doi.org/10.1016/j.fertnstert.2013.01.117

Jahan, S., Rehman, S., Ullah, H., Munawar, A., Ain, Q. U., \& Iqbal, T. (2016). Ameliorative effect of quercetin against arsenic-induced sperm DNA damage and daily sperm production in adult male rats. Drug and Chemical Toxicology, 39(3), 290-296. https://doi.org/10.3109/01480545.2015.1101772

Jenkins, T. G., James, E. R., Alonso, D. F., Hoidal, J. R., Murphy, P. J., Hotaling, J. M., ... Aston, K. I. (2017). Cigarette smoking significantly alters sperm DNA methylation patterns. Andrology, 5(6), 1089-1099. https://doi.org/10.1111/andr.12416

Ji, G., Yan, L., Liu, W., Qu, J., \& Gu, A. (2013). OGG1 Ser326Cys polymorphism interacts with cigarette smoking to increase oxidative DNA damage in human sperm and the risk of male infertility. Toxicology Letters, 218(2), 144-149. https://doi.org/10.1016/j. toxlet.2013.01.017

Jurewicz, J., Radwan, M., Sobala, W., Polanska, K., Radwan, P., Jakubowski, L., ... Hanke, W. (2015). The relationship between exposure to air pollution and sperm disomy. Environmental and Molecular Mutagenesis, 56(1), 50-59. https://doi.org/10.1002/em.21883

Kim, S. K., Jee, B. C., \& Kim, S. H. (2015). Histone methylation and acetylation in ejaculated human sperm: Effects of swim-up and smoking. Fertility and Sterility, 103(6), 14251431. https://doi.org/10.1016/j. fertnstert.2015.03.007

Kiziler, A. R., Aydemir, B., Onaran, I., Alici, B., Ozkara, H., Gulyasar, T., \& Akyolcu, M. C. (2007). High levels of cadmium and lead in seminal fluid and blood of smoking men 
are associated with high oxidative stress and damage in infertile subjects. Biological Trace Element Research, 120(1-3), 82-91. https://doi.org/10.1007/s12011-007-8020-8

Klebaner, D., Huang, Y., Hui, Q., Taylor, J. Y., Goldberg, J., Vaccarino, V., \& Sun, Y. V. (2016). $\mathrm{X}$ chromosome-wide analysis identifies DNA methylation sites influenced by cigarette smoking. Clinical Epigenetics, 8, 20. https://doi.org/10.1186/s13148-016-0189-2

Kobayashi, N., Miyauchi, N., Tatsuta, N., Kitamura, A., Okae, H., Hiura, H.,... Arima, T. (2017). Factors associated with aberrant imprint methylation and oligozoospermia. Scientific Reports, 7, 42336. https://doi. org/10.1038/srep42336

Kobayashi, H., Sato, A., Otsu, E., Hiura, H., Tomatsu, C., Utsunomiya, T.,... Arima, T. (2007). Aberrant DNA methylation of imprinted loci in sperm from oligospermic patients. Human Molecular Genetics, 16(21), 2542-2551. https://doi.org/10.1093/hmg/ddm187

Kotaja, N. (2014). MicroRNAs and spermatogenesis. Fertility and Sterility, 101(6), 1552-1562. https://doi.org/10.1016/j. fertnstert.2014.04.025

Kumosani, T., Elshal, M., Al-Jonaid, A., \& Abduljabar, H. (2008). The influence of smoking on semen quality, seminal microelements and Ca 2+-ATPase activity among infertile and fertile men. Clinical Biochemistry, 41(14), 1199-1203. https://doi.org/10.1016/j. clinbiochem.2008.07.013

La Maestra, S., De Flora, S., \& Micale, R. T. (2015). Effect of cigarette smoke on DNA damage, oxidative stress, and morphological alterations in mouse testis and spermatozoa. International Journal of Hygiene and Environmental Health, 218(1), 117-122. https://doi.org/10.1016/j.ijheh.2014.08.006

Lähdetie, J. (1986). Micronucleated spermatids in the seminal fluid of smokers and nonsmokers. Mutation Research/Genetic Toxicology, 172(3), 255-263. https://doi.org/10.1016/0165-1218(86)90063-7

Laqqan, M., Tierling, S., Alkhaled, Y., Porto, C. L., Solomayer, E. F., \& Hammadeh, M. E. (2017). Aberrant DNA methylation patterns of human spermatozoa in current smoker males. Reproductive Toxicology, 71, 126-133. https://doi.org/10.1016/j.reprotox.2017.05.010

Lee, M. K., Hong, Y., Kim, S. Y., London, S. J., \& Kim, W. J. (2016). DNA methylation and smoking in Korean adults: Epigenome-wide association study. Clinical Epigenetics, 8, 103. https://doi.org/10.1186/ s13148-016-0266-6

Lee, K. W., \& Pausova, Z. (2013). Cigarette smoking and DNA methylation. Frontiers in Genetics, 4, 132. https://doi.org/10.3389/ fgene.2013.00132

Li, X. P., Hao, C. L., Wang, Q., Yi, X. M., \& Jiang, Z. S. (2016). H19 gene methylation status is associated with male infertility. Experimental and Therapeutic Medicine, 12(1), 451456. https://doi.org/10.3892/ etm.2016.3314

Lodovici, M., Akpan, V., Evangelisti, C., \& Dolara, P. (2004). Sidestream tobacco smoke as the main predictor of exposure to polycyclic aromatic hydrocarbons. Journal of Applied Toxicology, 24(4), 277-281. https://doi.org/10.1002/jat.992

Lopes, S., Sun, J. G., Jurisicova, A., Meriano, J., \& Casper, R. F. (1998). Sperm deoxyribonucleic acid fragmentation is increased in poor-quality semen samples 
and correlates with failed fertilization in intracytoplasmic sperm injection. Fertility and Sterility, 69(3), 528-532.

Lugon-Moulin, N., Martin, F., Krauss, M. R., Ramey, P. B., \& Rossi, L. (2006). Cadmium concentration in tobacco (Nicotiana tabacum L.) from different countries and its relationship with other elements. Chemosphere, 63(7), 1074-1086.

Luzhna, L., Kathiria, P., \& Kovalchuk, O. (2013). Micronuclei in genotoxicity assessment: From genetics to epigenetics and beyond. Frontiers in Genetics, 4, 131. https://doi.org/10.3389/fgene.2013.00131

Maccani, M. A., \& Knopik, V. S. (2012). Cigarette smoke exposure-associated alterations to non-coding RNA. Front Genet, 3, 53. https://doi. org/10.3389/fgene.2012.00053

Mak, V., Jarvi, K., Buckspan, M., Freeman, M., Hechter, S., \& Zini, A. (2000). Smoking is associated with the retention of cytoplasm by human spermatozoa. Urology, 56(3), 463-466. https://doi. org/10.1016/Soo90-4295(00)00700-7

Male Infertility Best Practice Policy Committee of the American Urological Association, \& Practice Committee of the American Society for Reproductive Medicine. (2006). Report on optimal evaluation of the infertile male. Fertility and Sterility, 86(5), S2O2S209.

Marchetti, F., Rowan-Carroll, A., Williams, A., Polyzos, A., Berndt-Weis, M. L., \& Yauk, C. L. (2011). Sidestream tobacco smoke is a male germ cell mutagen. Proceedings of the National Academy of Sciences USA, 108(31), 12811-12814. https://doi.org/10.1073/pnas.1106896108

Marczylo, E. L., Amoako, A. A., Konje, J. C., Gant, T. W., \& Marczylo, T. H. (2012). Smoking induces differential miRNA expression in human spermatozoa: A potential transgenerational epigenetic concern? Epigenetics, $7(5), \quad 432-439$. https://doi.org/10.4161/epi.19794

Marques, C. J., Costa, P., Vaz, B., Carvalho, F., Fernandes, S., Barros, A., \& Sousa, M. (2008). Abnormal methylation of imprinted genes in human sperm is associated with oligozoospermia. Molecular Human Reproduction, 14(2), 67-74. https://doi.org/10.1093/molehr/gamo93

Mehdi, M., Khantouche, L., Ajina, M., \& Saad, A. (2009). Detection of DNA fragmentation in human spermatozoa: Correlation with semen parameters. Andrologia, 41(6), 383-386. https://doi.org/10.1111/j.1439-0272.2009.00953.x Mendiola, J., Torres-Cantero, A. M., Moreno-Grau, J. M., Ten, J., Roca, M., Moreno-Grau, S., \& Bernabeu, R. (2008). Exposure to environmental toxins in males seeking infertility treatment: A case-controlled study. Reproductive Biomedicine Online, 16(6), 842-850. https://doi. org/10.1016/S1472-6483(10)60151-4

Meri, Z. B., Irshid, I. B., Migdadi, M., Irshid, A. B., \& Mhanna, S. A. (2013). Does cigarette smoking affect seminal fluid parameters? A Comparative Study. Oman Medical Journal, 28(1), 12. https://doi. org/10.5001/omj.2013.03

Metzler-Guillemain, C., Victorero, G., Lepoivre, C., Bergon, A., Yammine, M., Perrin, J., ... Nguyen, C. (2015). Sperm mRNAs and microRNAs as candidate markers for the impact of toxicants on human spermatogenesis: An application to tobacco smoking. Systems Biology in Reproductive Medicine, 61(3), 139-149. https://doi.org/10.3109/19396368.2015.1022835 
Micillo, A., Vassallo, M. R., Cordeschi, G., D'Andrea, S., Necozione, S., Francavilla, F., ... Barbonetti, A. (2016). Semen leukocytes and oxidative-dependent DNA damage of spermatozoa in male partners of subfertile couples with no symptoms of genital tract infection. Andrology, 4(5), 808-815. https://doi.org/10.1111/andr.12188

Milosevic-Djordjevic, O., Stosic, I., Grujicic, D., Zelen, I., \& Sazdanovic, P. (2012). Chromosomal instability in peripheral blood lymphocytes of patients with reproductive failure assessed by micronucleus assay. Archives of Industrial Hygiene and Toxicology, 63(3),367-375.https:// doi.org/10.2478/10004-1254-63-2012-2225

Moazzam, A., Sharma, R., \& Agarwal, A. (2015). Relationship of sperma- tozoal DNA fragmentation with semen quality in varicocele-positive men. Andrologia, 47(8), 935-944. https://doi.org/10.1111/and.12360

Montjean, D., Zini, A., Ravel, C., Belloc, S., Dalleac, A., Copin, H.,... Benkhalifa, M. (2015). Sperm global DNA methylation level: Association with semen parameters and genome integrity. Andrology, 3(2), 235-240. https://doi.org/10.1111/andr.12001

Mostafa, T. (2010). Cigarette smoking and male infertility. Journal of Advanced Research, 1(3), 179-186. https://doi.org/10.1016/j. jare.2010.05.002

Mostafa, T., Tawadrous, G., Roaia, M., Amer, M., Kader, R., \& Aziz, A. (2006). Effect of smoking on seminal plasma ascorbic acid in infertile and fertile males. Andrologia, 38(6), 221-224. https://doi. org/10.1111/j.1439-0272.2006.00744.x

Muratori, M., Tamburrino, L., Marchiani, S., Cambi, M., Olivito, B., Azzari, C., ... Baldi, E. (2015). Investigation on the origin of sperm DNA fragmentation: Role of apoptosis, immaturity and oxidative stress. Molecular Medicine, 21, 109-122. https://doi.org/10.2119/ molmed.2014.00158

Nuti, F., \& Krausz, C. (2008). Gene polymorphisms/mutations relevant to abnormal spermatogenesis. Reprod Biomed Online, 16(4), 504-513. https://doi.org/10.1016/S1472-6483(10)60457-9

Oldereid, N. B., Rui, H., \& Purvis, K. (1992). Lifestyles of men in barren couples and their relationships to sperm quality. European Journal of Obstetrics \& Gynecology and Reproductive Biology, 43(1), 51-57. https://doi.org/10.1016/o028-2243(92)90243-R

Oliva, R. (2006). Protamines and male infertility. Human Reproduction Update, 12(4), 417-435. https://doi.org/10.1093/humupd/dmloo9

Osser, S., Beckman-Ramirez, A., \& Liedholm, P. (1992). Semen quality of smoking and non-smoking men in infertile couples in a Swedish population. Acta Obstetricia Et Gynecologica Scandinavica, $\quad 71(3), \quad 215^{-218 .}$ https://doi.org/10.3109/00016349209009921

Oyeyipo, I. P., Raji, Y., \& Bolarinwa, A. F. (2013). Nicotine alters male reproductive hormones in male albino rats: The role of cessation. Journal of Human Reproductive Sciences, 6(1), 40. https://doi. org/10.4103/0974-1208.112380

Ozgur, K., Isikoglu, M., Seleker, M., \& Donmez, L. (2005). Semen quality of smoking and non-smoking men in infertile couples in a Turkish population. Archives of Gynecology and Obstetrics, 271(2), 109-112. https://doi.org/10.1007/s00404-003-0572-Z

Pacifici, R., Altieri, I., Gandini, L., Lenzi, A., Pichini, S., Rosa, M., ... Dondero, F. (1993). Nicotine, cotinine, and trans-3-hydroxycotine levels in seminal plasma of smokers: 
Effects on sperm parameters. Therapeutic Drug Monitoring, 15(5), 358-363. https://doi.org/10.1097/00007691-199310000-00002

Papachristou, F., Simopoulou, M., Touloupidis, S., Tsalikidis, C., Sofikitis, N., \& Lialiaris, T. (2008). DNA damage and chromosomal aberrations in various types of male factor infertility. Fertility and Sterility, 90(5), 1774-1781. https://doi.org/10.1016/j.fertnstert.2007.09.006

Pappas, R., Polzin, G., Zhang, L., Watson, C., Paschal, D., \& Ashley, D. (2006). Cadmium, lead, and thallium in mainstream tobacco smoke particulate. Food and Chemical Toxicology, 44(5), 714-723. https:// doi.org/10.1016/j.fct.2005.10.004

Pasqualotto, F. F., Sobreiro, B. P., Hallak, J., Pasqualotto, E. B., \& Lucon, A. M. (2006). Cigarette smoking is related to a decrease in semen volume in a population of fertile men. $\quad B J U \quad$ International, 97(2), 324-326. https://doi.org/10.1111/j.1464-410X.2005.05906.x

Pekarsky, A., Rust, P., Varn, E., Mathur, R., \& Mathur, S. (1995). Effects of nicotine on sperm attachment and penetration of zona-free hamster eggs. Archives of Andrology, 34(2), 77-82. https://doi. org/10.3109/01485019508987834

Pereira, C. S., Juchniuk de Vozzi, M. S., Dos Santos, S. A., Vasconcelos, M. A., de Paz, C. C., Squire, J. A., \& Martelli, L. (2014). Smoking-induced chromosomal segregation anomalies identified by FISH analysis of sperm. Molecular Cytogenetics, 7(1), 58. https://doi.org/10.1186/ s13039-014-0058-7

Perrin, J., Tassistro, V., Mandon, M., Grillo, J.-M., Botta, A., \& Sari- Minodier, I. (2011). Tobacco consumption and benzo (a) pyrenediol-epoxide-DNA adducts in spermatozoa: In smokers, swim-up procedure selects spermatozoa with decreased DNA damage. Fertility and Sterility, 95(6), 2013-2017. https://doi.org/10.1016/j. fertnstert.2011.02.021

Petruzzelli, S., Tavanti, L. M., Pulera, N., Fornai, E., Puntoni, R., Celi, A., \& Giuntini, C. (2000). Effects of nicotine replacement therapy on markers of oxidative stress in cigarette smokers enrolled in a smoking cessation program. Nicotine \& Tobacco Research, 2(4), 345-350. https:// doi.org/10.1080/713688155

Petzold, A. M., Balciunas, D., Sivasubbu, S., Clark, K. J., Bedell, V. M., Westcot, S. E., ... Ekker, S. C. (2009). Nicotine response genetics in the zebrafish. Proceedings of the National Academy of Sciences USA, 106(44), 18662-18667. https://doi.org/10.1073/pnas.0908247106

Phillips, D. H., \& Venitt, S. (2012). DNA and protein adducts in human tissues resulting from exposure to tobacco smoke. International Journal of Cancer, 131(12), 2733-2753. https://doi.org/10.1002/ijc.27827

Rajender, S., Avery, K., \& Agarwal, A. (2011). Epigenetics, spermatogenesis and male infertility. Mutation Research/Reviews in Mutation Research, 727(3), 62-71. https://doi.org/10.1016/j.mrrev.2011.04.002

Rajesh Kumar, T., Doreswamy, K., Shrilatha, B., \& Muralidhara., (2002). Oxidative stress associated DNA damage in testis of mice: Induction of abnormal sperms and effects on $\begin{array}{llll}\text { fertility. } \quad \text { Mutation } \quad \text { Research, } & \text { 513(1- } & 2 \text { ), } & 103-111 .\end{array}$ https://doi.org/10.1016/S1383-5718(01)oo30o-X 
Ramaswamy, S., \& Weinbauer, G. F. (2014). Endocrine control of spermatogenesis: Role of FSH and LH/testosterone. Spermatogenesis, 4(2), e996025. https://doi.org/10.1080/21565562.2014.996025

Rubes, J., Lowe, X., Moore, D., Perreault, S., Slott, V., Evenson, D., ... Wyrobek, A. J. (1998). Smoking cigarettes is associated with increased sperm disomy in teenage men. Fertility and Sterility, 7O(4), 715-723.

Sadeu, J., Hughes, C. L., Agarwal, S., \& Foster, W. G. (2010). Alcohol, drugs, caffeine, tobacco, and environmental contaminant exposure: Reproductive health consequences and clinical implications. Critical Reviews in Toxicology, 40(7), 633652. https://doi.org/10.3109/10408444.2010.493552

Saleh, R. A., Agarwal, A., Sharma, R. K., Nelson, D. R., \& Thomas, A. J. (2002). Effect of cigarette smoking on levels of seminal oxidative stress in infertile men: A prospective study. Fertility and Sterility, 78(3), 491-499. https://doi.org/10.1016/Soo15-0282(02)03294-6

Samplaski, M. K., Dimitromanolakis, A., Lo, K. C., Grober, E. D., Mullen, B., Garbens, A., \& Jarvi, K. A. (2015). The relationship between sperm viability and DNA fragmentation rates. Reproductive Biology and Endocrinology, 13, 42. https://doi.org/10.1186/s12958-015-0035-y

Sepaniak, S., Forges, T., Gerard, H., Foliguet, B., Bene, M. C., \& Monnier-Barbarino, P. (2006). The influence of cigarette smoking on human sperm quality and DNA fragmentation. Toxicology, 223(1-2), 54-60. https://doi.org/10.1016/j.tox.2006.03.001

Sharma, R., Harlev, A., Agarwal, A., \& Esteves, S. C. (2016). Cigarette smoking and semen quality: A new meta-analysis examining the effect of the 2010 World Health Organization laboratory methods for the examination of human semen. European Urology, 70 (4), 635-645. https://doi.org/10.1016/j.eururo.2016.04.010

Shen, H.-M., \& Ong, C.-N. (2000). Detection of oxidative DNA damage in human sperm and its association with sperm function and male infertility. Free Radical Biology and Medicine, 28(4), 529-536. https:// doi.org/10.1016/So891-5849(99)oo234-8

Shi, Q., Ko, E., Barclay, L., Hoang, T., Rademaker, A., \& Martin, R. (2001). Cigarette smoking and aneuploidy in human sperm. Molecular Reproduction and Development, 59(4), 417-421. https://doi. org/10.1002/mrd.1048

Shi, Q., \& Martin, R. (2000). Aneuploidy in human sperm: A review of the frequency and distribution of aneuploidy, effects of donor age and lifestyle factors. Cytogenetics and Cell Genetics, 9o(3), 219-226. https://doi.org/10.1159/000056773

Singh, K. P., \& DuMond, J. W. Jr (2007). Genetic and epigenetic changes induced by chronic low dose exposure to arsenic of mouse testicular Leydig cells. International Journal of Oncology, 3o(1), 253-260. https://doi.org/10.3892/ijo.30.1.253

Sun, J. G., Jurisicova, A., \& Casper, R. F. (1997). Detection of deoxyribonucleic acid fragmentation in human sperm: Correlation with fertilization in vitro. Biology of Reproduction, 56(3), 602-607. 
Sundar, I. K., Yao, H., \& Rahman, I. (2013). Oxidative stress and chromatin remodeling in chronic obstructive pulmonary disease and smoking-related diseases. Antioxidants \& Redox Signaling, 18(15), 1956-1971. https://doi.org/10.1089/ars.2012.4863

Taha, E. A., Ezz-Aldin, A. M., Sayed, S. K., Ghandour, N. M., \& Mostafa, T. (2014). Smoking influence on sperm vitality, DNA fragmentation, reactive oxygen species and zinc in oligoasthenoteratozoospermic men with varicocele. Andrologia, 46(6), 687-691. https://doi.org/10.1111/ and.12136

Templado, C., Marquez, C., Munne, S., Colls, P., Martorell, M., Cieply, K., ... Estop, A. (1996). An analysis of human sperm chromosome aneuploidy. Cytogenetic and Genome Research, 74(3), 194-200.https://doi. org/10.1159/000134413

Templado, C., Uroz, L., \& Estop, A. (2013). New insights on the origin and relevance of aneuploidy in human spermatozoa. Molecular Human Reproduction, 19(10), 634643. https://doi.org/10.1093/molehr/ gato39

Trkova, M., Kapras, J., Bobkova, K., Stankova, J., \& Mejsnarova, B. (2000). Increased micronuclei frequencies in couples with reproductive failure. Reproductive Toxicology, 14(4), 331-335. https://doi. org/10.1016/So890-6238(oo)ooo87-3

Urdinguio, R. G., Bayon, G. F., Dmitrijeva, M., Torano, E. G., Bravo, C., Fraga, M. F., ... Fernandez, A. F. (2015). Aberrant DNA methylation patterns of spermatozoa in men with unexplained infertility. Human Reproduction, 3O(5), 1014-1028. https://doi.org/10.1093/humrep/ dev053

Viloria, T., Meseguer, M., Martínez-Conejero, J. A., O'Connor, J., Remohí, J., Pellicer, A., \& Garrido, N. (2010). Cigarette smoking affects specific sperm oxidative defenses but does not cause oxidative DNA damage in infertile men. Fertility and Sterility, 94(2), 631-637.https:// doi.org/10.1016/j.fertnstert.2009.03.024

Vine, M., Margolin, B., Morrison, H., \& Hulka, B. (1994). Cigarette smoking and sperm density: A meta-analysis. Fertility and Sterility, 61(1), 35-43.

Vine, M., Tse, C.-K., Hu, P., \& Truong, K. Y. (1996). Cigarette smoking and semen quality. Fertility and Sterility, 65(4), 835-842. https://doi. org/10.1016/Soo15-0282(16)58223-5

Wang, X., Zhang, J., Xu, W., Huang, Q., Liu, L., Tian, M., ... Shen, H. (2016). Low-level environmental arsenic exposure correlates with unexplained male infertility risk. Science of the Total Environment, 571, 307-313. https://doi.org/10.1016/j.scitotenv.2016.07.169

Wdowiak, A., Bakalczuk, S., \& Bakalczuk, G. (2015). The effect of sperm DNA fragmentation on the dynamics of the embryonic development in intracytoplasmatic sperm injection. Reproductive Biology, 15(2), 94-100. https://doi.org/10.1016/j.repbio.2015.03.003

Wilson, D. M., \& Thompson, L. H. (2007). Molecular mechanisms of sister-chromatid exchange. Mutation Research/Fundamental and Molecular Mechanisms of Mutagenesis, 616(1), 11-23. https://doi.org/10.1016/j. mrfmmm.2006.11.017

Wong, M. K., Barra, N. G., Alfaidy, N., Hardy, D. B., \& Holloway, A. C. (2015). Adverse effects of perinatal nicotine exposure on reproductive outcomes. Reproduction, 15O(6), R185-R193. https://doi. org/10.1530/REP-15-O295 
Wong, W. Y., Thomas, C. M., Merkus, H. M., Zielhuis, G. A., Doesburg, W. H., \& Steegers-Theunissen, R. P. (2000). Cigarette smoking and the risk of male factor subfertility: Minor association between cotinine in seminal plasma and semen morphology. Fertility and Sterility, 74(5), 930-935. https://doi.org/10.1016/Soo15-0282(oo)01567-3

Wu, H.-M., Lin-Tan, D.-T., Wang, M.-L., Huang, H.-Y., Lee, C.-L., Wang, H.-S., ... Lin, J.-L. (2012). Lead level in seminal plasma may affect semen quality for men without occupational exposure to lead. Reproductive Biology and Endocrinology, 1O(1), 91. https://doi. org/10.1186/1477-7827-10-91

Xu, W., Fang, P., Zhu, Z., Dai, J., Nie, D., Chen, Z., ... Qiao, Z. (2013). Cigarette smoking exposure alters pebp1 DNA methylation and protein profile involved in MAPK signaling pathway in mice testis. Biology of Reproduction, 89(6), 142. https://doi.org/10.1095/ biolreprod.113.111245

Xu, J., Zhang, A., Zhang, Z., Wang, P., Qian, Y., He, L., ... Du, J. (2016). DNA methylation levels of imprinted and nonimprinted genes DMRs associated with defective human spermatozoa. Andrologia, 48(9), 939-947. https://doi.org/10.1111/and.12535

Yang, F., Li, L., Chen, J. P., Liu, X. Q., Zhong, C. L., Yang, Y., ... Miao, M. H. (2016). Couple's infertility in relation to male smoking in a Chinese rural area. Asian Journal of Andrology, 19(3), 311. https://doi. org/10.4103/1008-682X.168685

Yarosh, S., Kokhtenko, E., Churnosov, M., Solodilova, M., \& Polonikov, A. (2014). Joint effect of glutathione S-transferase genotypes and cigarette smoking on idiopathic male infertility. Andrologia, 47(9), 980-986.

Yarosh, S. L., Kokhtenko, E. V., Starodubova, N. I., Churnosov, M. I., \& Polonikov, A. V. (2013). Smoking status modifies the relation between $\mathrm{CYP}_{1} \mathrm{~A}_{1}{ }_{2} \mathrm{C}$ gene polymorphism and idiopathic male infertility: The importance of gene-environment interaction analysis for genetic studies of the disease. Reproductive Sciences, 2O(11), 1302- 1307. https://doi.org/10.1177/1933719113483013

Yauk, C. L., Berndt, M. L., Williams, A., Rowan-Carroll, A., Douglas, G. R., \& Stampfli, M. R. (2007). Mainstream tobacco smoke causes paternal germ-line DNA mutation. Cancer Research, 67(11), 5103-5106. https://doi.org/10.1158/0008-5472.CAN-07-0279

Yu, B., Chen, J., Liu, D., Zhou, H., Xiao, W., Xia, X., \& Huang, Z. (2013). Cigarette smoking is associated with human semen quality in synergy with functional NRF2 polymorphisms. Biology of Reproduction, $89(1), \quad 5$. https://doi.org/10.1095/biolreprod.113.109389

Yu, B., Ding, Q., Zheng, T., Jiang, L., Li, Q., Sun, X., ... Huang, Z. (2014). Smoking attenuated the association between IкB $\alpha$ rs696 polymorphism and defective spermatogenesis in humans. Andrologia, 47(9), 987-994.

Yu, B., \& Huang, Z. (2015). Variations in antioxidant genes and male infertility. BioMed Research International, 2015, 1-10. https://doi. org/10.1155/2015/513196

Yu, B., Qi, Y., Liu, D., Gao, X., Chen, H., Bai, C., \& Huang, Z. (2014). Cigarette smoking is associated with abnormal histone-to-protamine transition in human sperm. Fertility and Sterility, 101(1), 51-57, e51. https://doi.org/10.1016/j.fertnstert.2013.09.001

Zeilinger, S., Kuhnel, B., Klopp, N., Baurecht, H., Kleinschmidt, A., Gieger, C., ... Illig, T. (2013). Tobacco smoking leads to extensive genome-wide changes in DNA 
$\begin{array}{lllll}\text { methylation. } & \text { PLoS } & \text { One, } & \text { 8(5), } & \text { e63812. }\end{array}$ doi.org/10.1371/journal.pone.0063812

Zenzes, M. T. (2000). Smoking and reproduction: Gene damage to human gametes and embryos. Human Reproduction Update, 6(2), 122-131. https://doi.org/10.1093/humupd/6.2.122

Zenzes, M. T., Bielecki, R., \& Reed, T. E. (1999). Detection of benzo (a) pyrene diol epoxide-DNA adducts in sperm of men exposed to cigarette smoke. Fertility and Sterility, 72(2), 330-335. https://doi. org/10.1016/So015-0282(99)00230-7

Zenzes, M. T., Puy, L. A., Bielecki, R., \& Reed, T. E. (1999). Detection of benzo [a] pyrene diol epoxide-DNA adducts in embryos from smoking couples: Evidence for transmission by spermatozoa. Molecular Human Reproduction, 5(2), 125-131. https://doi.org/10.1093/ molehr/5.2.125

Zhu, X., Li, J., Deng, S., Yu, K., Liu, X., Deng, Q., ... Wu, T. (2016). Genome-wide analysis of DNA methylation and cigarette smoking in a Chinese population. Environmental Health Perspectives, 124(7), 966-973. https://doi.org/10.1289/ehp.1509834

Zidi-Jrah, I., Hajlaoui, A., Mougou-Zerelli, S., Kammoun, M., Meniaoui, I., Sallem, A., ... Ibala-Romdhane, S. (2016). Relationship between sperm aneuploidy, sperm DNA integrity, chromatin packaging, traditional semen parameters, and recurrent pregnancy loss. Fertility and Sterility, 105(1), 58-64. https://doi.org/10.1016/j.fertnstert.2015.09.041 